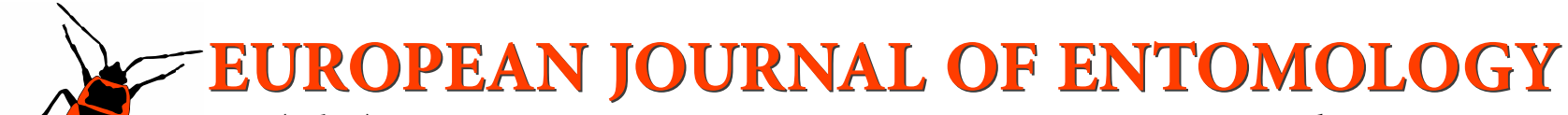 \\ ISSN (online): 1802-8829 \\ http://www.eje.cz \\ Eur. J. Entomol. 115: 167-191, 2018 \\ doi: 10.14411/eje.2018.016 \\ ORIGINAL ARTICLE
}

\section{Two new species and one new record for the genus Copris (Coleoptera: Scarabaeidae: Scarabaeinae) from Vietnam with a key to Vietnamese species}

\author{
Van Bac BUI ${ }^{1,2}$, KenNeth DUMACK ${ }^{1}$ and Michael BONKOWSKI ${ }^{1}$ \\ ${ }^{1}$ Institute of Zoology, Terrestrial Ecology, University of Cologne, Zülpicher Strasse 47b, D-50674 Cologne, Germany; e-mails: \\ vbui3@smail.uni-koeln.de, kenneth.dumack@uni-koeln.de, M.Bonkowski@uni-koeln.de \\ ${ }^{2}$ Department of Plant Protection, Faculty of Forest Resources and Environmental Management, Vietnam National University \\ of Forestry, Xuan Mai, Chuong My, Hanoi, Vietnam; e-mail: buibac80@gmail.com
}

Key words. Coleoptera, Scarabaeidae, Copris, taxonomy, new species, key, distribution, Oriental region, Vietnam, Caobang, Thanhhoa

\begin{abstract}
Two new species of Copris Geoffroy, 1762 are described and illustrated: Copris (subgenus incertae sedis) caobangensis sp. n. from Caobang Province (northern Vietnam) and Copris (Copris) sonensis sp. n. from Thanhhoa Province (central Vietnam). Copris (Copris) szechouanicus Balthasar, 1958 is recorded in Vietnam for the first time and data on the morphology, distribution and ecology of this species are given. An updated species list and an identification key for the Copris species so far known from Vietnam are presented along with detailed photographs of the poorly known species.
\end{abstract}

ZooBank Article LSID: 6DF5C431-52C2-45F6-8DF1-72BABC998336

\section{INTRODUCTION}

Copris Geoffroy, 1762 is placed in the group "tunnelers" of true dung beetles, comprising species of different body sizes and with various nesting strategies. Small tunnelers (less than $13 \mathrm{~mm}$ ) make shallow nests with many brood masses, while large species make deep nests, containing fewer brood masses (Hanski \& Cambefort, 1991). The genus is widely distributed in Africa, North and Central America, as well as in the Palaearctic and Oriental regions, and currently includes over 230 described species (Davis et al., 2008). Although species of Copris have been investigated for a long time, some groups, especially the Southeast Asian species are still poorly known. As only a few Vietnamese Copris species are described by Gillet (1911), Arrow (1931), Kabakov (1994), Hanboonsong et al. (2003) and Ochi \& Kon (2004) there is still a poor understanding of the taxa involved. This is partly due to its somewhat intricate taxonomy as species of Copris are separated by minor differences, such as the morphology of the pronotum and cephalic horn, or the structure of the elytra and tibia, etc. In order to avoid taxonomic confusion between $\mathrm{Co}$ pris species, an integrated taxonomic approach, combining morphological and molecular data, as well as a detailed species determination key are needed. During the course of our examination of dung beetles that were collected in limestone ecosystems in two spatially separated nature re- serves (NR) in Vietnam, we discovered two new species and established a new country record, increasing the number of known species of Copris from Vietnam to 21. Here we describe these two new species, provide a first species identification key and an updated list of Copris species from Vietnam, and provide data on the new record for this country.

\section{MATERIALS AND METHODS}

\section{Study area and sampling protocol}

The field research was conducted in limestone karst ecosystems in high mountain areas at Pu Luong (Thanhhoa Province) and Pia Oac NR (Caobang Province) between March and May over a two year period (2015-2016). We used in total 90 baited pitfall traps to collect dung beetles. The traps were placed in habitats with increasing land use intensity, comprising primary forests, secondary forests and meadows in both reserves. Each trap consisted of a 5-liter plastic bucket buried to its rim in the soil, filled with 21 of $70 \%$ ethanol, and baited with $300 \mathrm{~g}$ of fresh pig dung. Specimens were removed from the traps after $48 \mathrm{~h}$ of trap exposure and preserved in $70 \%$ ethanol until examined in the lab.

\section{Material examined}

Specimens examined for this study are deposited in the following institutions (curators in parentheses): VNUF - Vietnam National University of Forestry, Hanoi, Vietnam (Bùi Văn Bắc); PLNR - Pu Luong Nature Reserve, Quanhoa and Bathuoc districts, Thanhhoa Province, Vietnam (Nguyễn Bá Tâm); 
NMPC - National Museum, Prague, Czech Republic (Jiří Hájek); RMNH - Naturalis Biodiversity Center, Leiden, Netherlands (Hans Huijbregts).

\section{Morphometrics}

Measurements were taken with a digital caliper and from photographs taken through a digital microscope (Keyence VHX$500 \mathrm{~F}$ ). The following morphometric traits were measured: BoL - body length from anterior margin of clypeus to posterior margin of elytra; BoW - maximum body width; HeadL - head length from anterior most point of clypeus to posterior margin of head; HeadW - maximum head width; PronL - maximum pronotum length; PronW - maximum pronotum width; ElyL - elytra length from apex to base; MWoI123 - maximum width of first three interstriae from elytral suture; DP10-15 - distance from puncture 10 (from base of elytra) to puncture 15 on first elytral stria; $\mathrm{HoL}$ - horn length from base to tip; PyL - maximum pygidium length; PyW - maximum pygidium width; ProTiL - protibia length; ProTiW - maximum protibia width; ProTiSL - protibial spur length; MesoTiL - mesotibia length; MesoTiW - maximum mesotibia width; 1st MesoTiSL - 1st mesotibial spur length (longest spur); 2nd MesoTiSL - 2nd mesotibial spur length (shortest spur); MetaTiL - metatibia length from proximal constriction to apex; MetaTiW - maximum metatibia width; MetaTiSL - metatibial spur length; MetaTaL - metatarsus length; MetaTa1L - metatarsomere 1 length; MetaTa1W - metatarsomere 1 width; MetaTa5W - metatarsomere 5 width; DDC - distance between apices of clypeal denticles (teeth).

\section{Male genital morphology}

We used forceps and needles to open the pygidium for removing the aedeagus. The extracted aedeagus was cleaned and softened in $5 \% \mathrm{KOH}$ at $65^{\circ} \mathrm{C}$ for one hour before being placed in glycerin and photographed using a digital microscope (Medina et al., 2013).

\section{DNA extraction and sequencing}

Material for molecular analysis was obtained from Copris (Copris) sonensis sp. n. Genomic DNA was extracted from legs of two paratype specimens (1 male and 1 female), using DNeasy Blood \& Tissue Kit (Qiagen). PCR amplification of the cytochrome oxidase I gene was performed in a volume of $26 \mu 1$ that consisted of $14.85 \mu \mathrm{l}$ of sterile water, $2.5 \mu 1$ Green Buffer (10× ThermoFisher Scientific), $2.5 \mu 1$ of $2 \mu \mathrm{M}$ dNTPs, $2.5 \mu 1$ of each primer, $0.15 \mu 1$ DreamTaq polymerase (ThermoFisher Scientific) and $1 \mu 1$ extracted DNA. The primers used for amplifica- tion were Cox1 (5'-CAACATTTATTTTGATTTTTTGG-3') and Cox2 (5'-TCCAATGCACTAATCTGCCATATTA-3') (Wirta et al., 2008; Mlambo et al., 2015). Thermal cycling parameters had a denaturation phase of $95^{\circ} \mathrm{C}$ for $32 \mathrm{~s}$, extension at $72^{\circ} \mathrm{C}$ for 2 min and an annealing temperature of $50^{\circ} \mathrm{C}$ for $36 \mathrm{~s}$. The conditions were cycled 35 times. Amplification products were purified with Exo-SAP PCR cleanup, containing $8 \mu$ l PCR product, 1.95 $\mu 1$ sterile water, $0.9 \mu 1$ FastAP and $0.15 \mu 1$ Exonuclease (ThermoFisher Scientific). The mixture was incubated at $37^{\circ} \mathrm{C}$ for 30 minutes, followed by heating up to $85^{\circ} \mathrm{C}$ for $20 \mathrm{~min}$. The purified solution was diluted by adding $99 \mu 1$ sterile water before sequencing. Sequencing was conducted with the BigDye Terminator v3.1 Cycle Sequencing Kit (ThermoFisher Scientific). The sequencing was performed at Cologne Center for Genomics (CCG), University of Cologne, Germany. The new sequences were submitted to the NCBI database under the accession numbers MG642090 and MG642091.

\section{Molecular analysis}

COXI sequences of Copris (Copris) sonensis sp. n. and several other taxa of Copris, Catharsius Hope, 1837 (classified in Coprini) and Onthophagus Latreille, 1802 (formally used as outgroup, although this does not agree with the results of Monaghan et al., 2007) of Eurasian or African origin (Table 1) were manually aligned in SeaView (V4.5.3; Gouy et al., 2010). 837 sites were used for the alignment, of which $67.03 \%$ were invariant.

Trees were calculated in PhyML 3.1 (Maximum Likelihood; model $\mathrm{GTR}+\mathrm{I}+\mathrm{G}$, starting tree NJ, 100 bootstrap replicates; Guindon \& Gascuel, 2003) and MrBayes (settings: mcmc ngen = $1 \mathrm{M}$, sample freq $=100$, print freq $=100$, diagn freq $=500$; burnin of $25 \%$ and final split frequencies of less than 0.01 ; Altekar et al., 2004; Ronquist \& Huelsenbeck, 2003).

\section{TAXONOMY}

\section{Genus Copris Geoffroy, 1762}

Type species: Scarabaeus lunaris Linnaeus, 1758 (designated by Latreille, 1810).

\section{Copris (subg. incertae sedis) caobangensis sp. $\mathbf{n}$.}

Figs 1-13, 25

ZooBank taxon LSID:

3A4B3342-251B-471E-B9EC-56BDB94E26F4

Description of holotype male. Total body length 12 $\mathrm{mm}$, maximum body width $6.5 \mathrm{~mm}$. Colour: Dorsal sur-

Table 1. Species, localities, museum numbers and numbers of the GenBank accession used in the phylogenetic analysis.

\begin{tabular}{|c|c|c|c|c|}
\hline Species & Locality & Museum No. & $\begin{array}{c}\text { GenBank Accession } \\
\text { No. / COXI }\end{array}$ & Reference \\
\hline Copris sonensis sp. n. (ঐ) & Vietnam & VNUF, paratype & MG642090 & This study \\
\hline Copris sonensis sp. n. (ㅇ) & Vietnam & VNUF, paratype & MG642091 & This study \\
\hline Copris sinicus Hope, 1842 & Hong Kong & BMNH 679781 & AY131862 & Monaghan et al. (2007) \\
\hline Copris agnus Sharp, 1875 & Indonesia & BMNH 679776 & AY131857 & Monaghan et al. (2007) \\
\hline Copris amyntor Klug, 1855 & South Africa & BMNH 679777 & AY131858 & Monaghan et al. (2007) \\
\hline Copris lugubris Boheman, 1858 & Costa Rica & BMNH 679779 & AY131860 & Monaghan et al. (2007) \\
\hline "Copris aeneus" * & South Africa & BMNH 679775 & AY131856 & Monaghan et al. (2007) \\
\hline Catharsius molossus (Linnaeus, 1758) & Indonesia & BMNH 679772 & AY131853 & Monaghan et al. (2007) \\
\hline Catharsius sesostris Waterhouse, 1888 & South Africa & BMNH 679774 & AY131855 & Monaghan et al. (2007) \\
\hline Catharsius calaharicus Kolbe, 1893 & South Africa & BMNH 679771 & AY131852 & Monaghan et al. (2007) \\
\hline Catharsius philus Kolbe, 1893 & South Africa & BMNH 679773 & AY131854 & Monaghan et al. (2007) \\
\hline Onthophagus similis (Scriba, 1790) & Spain & BMNH 679871 & AY131933 & Monaghan et al. (2007) \\
\hline Copris confucius Harold, 1877 & Laos & MNHN & EF188135 & Wirta et al. (2008) \\
\hline Onthophagus nuchicornis (Linnaeus, 1758) & - & - & GQ889396 & Ahrens \& Roessner (unpubl.) \\
\hline
\end{tabular}

BMNH - Natural History Museum, London, UK; MNHN - Muséum national d'Histoire naturelle, Paris, France; * - not a valid name, perhaps Monaghan et al.'s error for Copris anceus (Olivier, 1789), a South African species. 


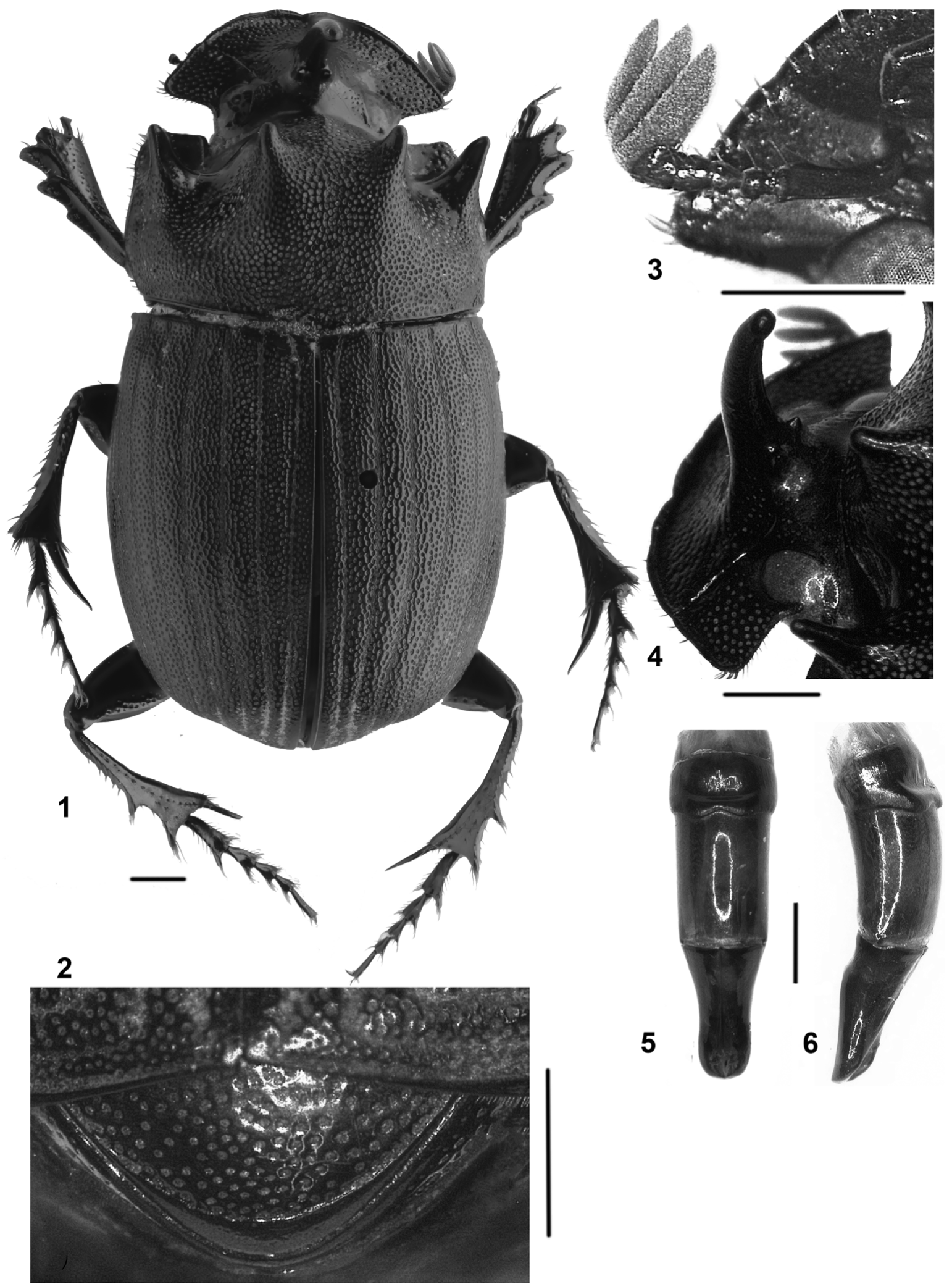

Figs 1-6. Copris cabangensis sp. n., male holotype. 1 - dorsal habitus; 2 - pygidium; 3 - right antenna ventral; 4 - horn; 5 - genitalia dorsal; 6 - genitalia lateral. Scale bars $1 \mathrm{~mm}$.

face chocolate brown. Ventral surface dark brown on head, shiny dark brown on thorax, abdomen and pygidium. Mouthparts, maxillary palpi, tarsi and antennomeres 1-6 reddish brown. Antennal club, setae on legs and sides of meso-metaventer yellow (Figs 1-6).
Head nearly semicircular, $2.5 \mathrm{~mm}$ long and $4.7 \mathrm{~mm}$ wide. Clypeal surface rugose and strongly punctate; clypeal apex weakly emarginated. Genae strongly and coarsely punctate. Vertex surface between eyes smooth, except for small areas near eyes sparsely punctate. Antenna with 9 anten- 


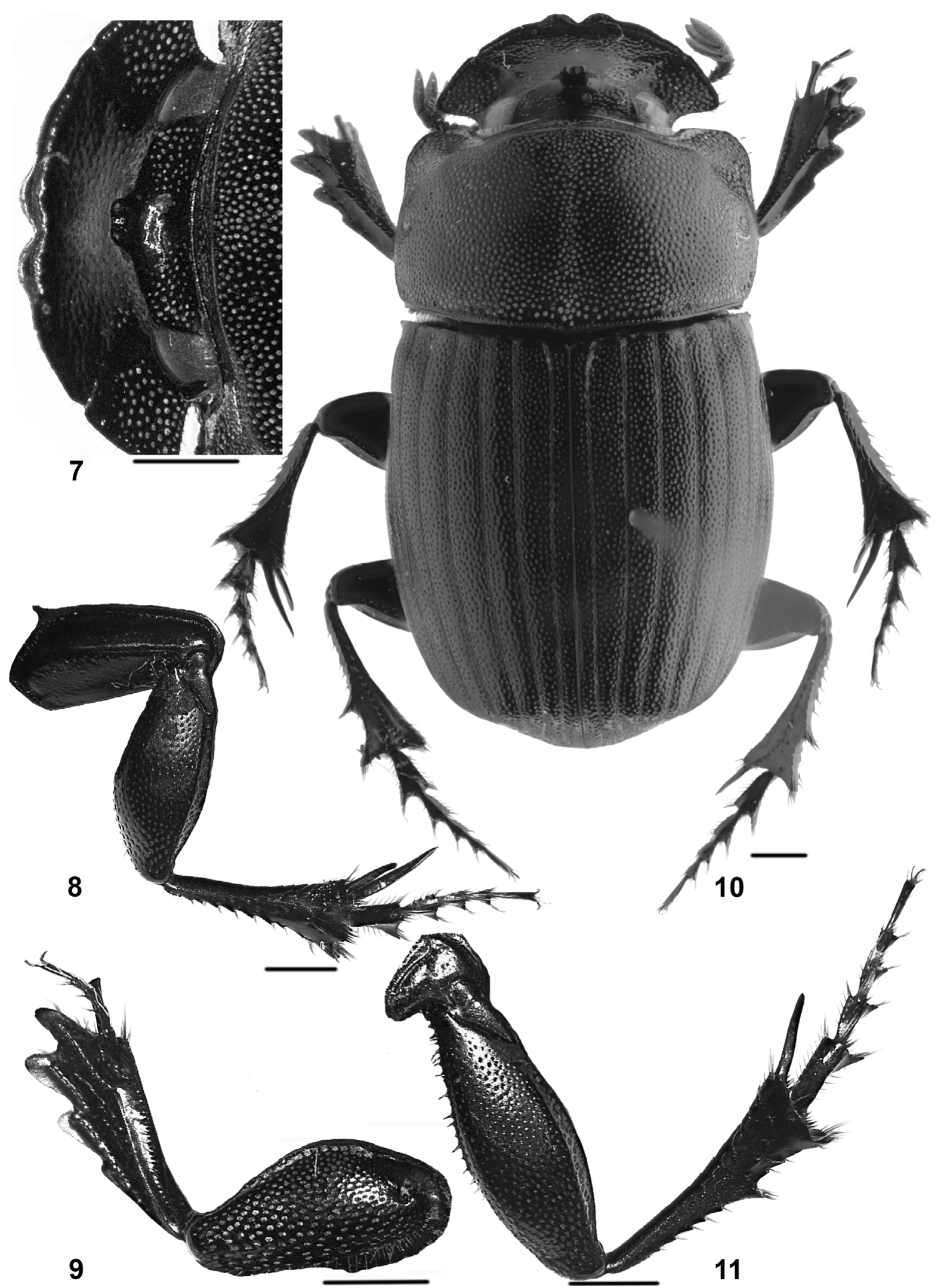

Figs 7-11. Copris caobangensis sp. n., female paratype. 7 - horn; 8 - right mesothoracic leg ventral; 9 - right prothoracic leg ventral; 10 - dorsal habitus; 11 - right metathoracic leg ventral. Scale bars $1 \mathrm{~mm}$.

nomeres; length of antennomere $10.9 \mathrm{~mm}$, equal in length to antennomeres 2-6 combined and also antennal club. Cephalic horn long and curved backwards (length $3 \mathrm{~mm}$ ); base of horn with two small but distinct teeth. Maxilla length $1.4 \mathrm{~mm}$, bearing slender palpi. Mentum with thick and yellow setae, obscuring its surface.

Pronotum with sharp anterior declivity, nearly vertical and each side deeply excavated. Anterior angles of prono- 
tum armed with two strong, upward and forward directed prominences on dorsum. Each side with one sharp, upward directed prominence. Pronotal disc with slight longitudinal sulcus; sulcus with chain of deep and dense punctures. Vertical anterior surface with strongly punctate carina running through its middle. Anterolateral angles of pronotum nearly square; anterior margins behind genae almost straight. Pronotal surface almost strongly, densely and equally punctate, except for quite small smooth areas of pronotal excavation. Pronotal prominences indistinctly punctate.

Elytra distinctly striate, with 10 complete striae. Each stria strongly and closely punctate (DP10-15 $0.7 \mathrm{~mm}$ ). Elytral interstriae convex, matt and strongly, equally, densely but separately punctate (Fig. 25).

Mesepimeron and metepisternum flat, rugose, and covered by yellow setae.

Meso-metaventral plate smooth; posterior part with median groove; anterior part with deep pit. Sides strongly punctate and sparsely setaceous.

Legs. Ventral surface of profemora, mesofemora and metafemora strongly, closely and equally punctate. Protibia (ProTiL $2.2 \mathrm{~mm}$, ProTiW $1.3 \mathrm{~mm}$ ) with four lateral teeth. Protibial spurs truncate and distinctly curved inwards near apex. Protibial spur length $0.8 \mathrm{~mm}$, equal in length to protarsomeres 1-3 combined. Protarsomere 5 and protarsomeres 3-4 combined equal in length $(0.5 \mathrm{~mm})$. Mesotibia (MesoTiL $2.3 \mathrm{~mm}$, MesoTiW $1.0 \mathrm{~mm}, 1^{\text {st }}$ MesoTiSL $1.4 \mathrm{~mm}, 2^{\text {nd }}$ MesoTiSL $0.7 \mathrm{~mm}$ ) and metatibia (MetaTiL $2.5 \mathrm{~mm}$, MetaTiW $0.9 \mathrm{~mm}$, MetaTiSL $0.8 \mathrm{~mm}$ ) broadly dilated at posterior end. Metatibia with strong transverse outer carina. Both mesotarsi and metatarsi short, bearing sparse yellow setae.

Abdomen. Pygidium length $0.9 \mathrm{~mm}$, width $2.2 \mathrm{~mm}$. Surface slightly convex, strongly, coarsely but not closely punctate. Abdominal ventrites sparsely punctate, becoming narrower at middle.

Aedeagus. Phallobase $1.8 \mathrm{~mm}$ in length with strong dorsal lobes. Parameres shorter than phallobase, approximately $1.3 \mathrm{~mm}$ in length. Broad angle of $146^{\circ}$ formed by phallobase and parameres.

Sexual dimorphism. Females differ from the male holotype in the following characters: Cephalic horn straight, short, $0.8 \mathrm{~mm}$ in length; horn apex excavated. Clypeal apex more strongly emarginated. Genae and vertex between eyes with more punctures. Pronotum with a deeper median sulcus on dorsal surface. Each side of pronotum unarmed and not excavated (Figs 7-11).

Differential diagnosis. Copris caobangensis sp. $\mathrm{n}$. is similar to species of the subgenus Paracopris Balthasar, 1939 in their strongly punctate elytral interstriae, but differs in its pronotal structures and the structure of the horn in males. Pronotum with sharp anterior declivity, armed and excavated in the male, transversely carinate on the upper part of the anterior declivity in the female in C. caobangensis sp. $\mathrm{n}$. while indistinct or slight declivity occurs in species of the subgenus Paracopris. In addition, males of $C$. caobangensis sp. n. have a longer cephalic horn. For these reasons, we leave this new species without a subgeneric classification and consider it as "subgenus incertae sedis". Almost all species of the nominotypical subgenus bear smooth, indistinctly punctate interstriae, which distinguishes them from the new species. Two species of the nominotypical subgenus, C. (Copris) punctatus Gillet, 1910 and $C$. (C.) saperdon Harold, 1868 have distinctly but not closely and strongly punctate interstriae. The new species can be easily distinguished from species of the subgenus Microcopris Balthasar, 1958 as the front angles of prothorax are deeply excavated in all species of the

Table 2. Morphometrics of Copris caobangensis sp. n., C. (Copris) sonensis sp. n. and C. (C.) szechouanicus (measurements in mm).

\begin{tabular}{|c|c|c|c|c|c|c|c|}
\hline & \multirow{2}{*}{ Character } & \multicolumn{2}{|c|}{ C. caobangensis sp. $\mathrm{n}$. } & \multicolumn{2}{|c|}{ C. sonensis sp. n. } & \multicolumn{2}{|c|}{ C. szechouanicus } \\
\hline & & Male $(n=1)$ & Female $(n=2)$ & Male $(n=6)$ & Female $(n=3)$ & Male $(n=8)$ & Female $(n=10)$ \\
\hline 1 & BoL & 12 & $11.8-12.0$ & $14-15.2$ & $13.3-14.9$ & $14.5-18.6$ & $16.7-18.1$ \\
\hline 2 & BoW & 6.5 & $6.3-6.6$ & $7.8-8.4$ & 7.3-8.0 & $8.4-10.0$ & $9.4-10.3$ \\
\hline 3 & HeadL & 2.5 & $2.4-2.7$ & $2.5-3.0$ & $2.8-3.1$ & $3.4-3.7$ & $3.4-4.9$ \\
\hline 4 & HeadW & 4.7 & $4.6-4.8$ & $5.2-5.5$ & $5.4-5.7$ & $6.1-6.6$ & $6.6-7.1$ \\
\hline 5 & PronL & 3.6 & 3.6 & $4.2-4.8$ & $4.1-4.7$ & $4.4-5.2$ & $5.1-6.0$ \\
\hline 6 & PronW & 6.2 & $5.9-6.1$ & $7.0-7.7$ & $6.8-7.4$ & $8.0-9.1$ & $8.9-9.6$ \\
\hline 7 & ElyL & 6.6 & $6.5-6.7$ & $7.7-8.4$ & $7.2-8.2$ & $8.6-10.1$ & $10.3-11.5$ \\
\hline 8 & MWol123 & 1.5 & 1.5 & $1.8-2.1$ & $1.9-2.0$ & $2.0-2.3$ & $1.6-2.5$ \\
\hline 9 & DP10-15 & 0.7 & $0.8-0.9$ & $0.8-1.1$ & $0.8-0.9$ & $1.1-1.4$ & $1.2-1.5$ \\
\hline 10 & $\mathrm{HoL}$ & 3 & 0.5 & $2.8-3.3$ & $0.8-0.9$ & $0.4-1.0$ & $0.7-1.1$ \\
\hline 11 & PyL & 0.9 & $0.9-1.1$ & $1.6-1.7$ & $1.6-1.7$ & $1.5-1.7$ & $1.5-2.0$ \\
\hline 12 & PyW & 2.2 & $2.3-2.5$ & $3.1-3.3$ & 3.3 & $3.3-3.8$ & $3.1-4.7$ \\
\hline 13 & ProTiL & 2.2 & $2.1-2.2$ & $2.0-2.8$ & $1.8-1.9$ & $2.9-3.2$ & $3.1-3.5$ \\
\hline 14 & ProTiW & 1.3 & $1.3-1.4$ & $1.0-1.6$ & $1.0-1.1$ & $1.5-1.8$ & $1.7-2.0$ \\
\hline 15 & ProTiSL & 0.8 & $0.6-0.7$ & $0.8-1.1$ & $0.6-0.7$ & $1.2-1.6$ & $1.0-1.1$ \\
\hline 16 & MesoTiL & 2.3 & $2.3-2.4$ & $2.5-2.8$ & $2.6-2.9$ & $2.9-3.1$ & $3.1-3.5$ \\
\hline 17 & MesoTiW & 1 & $1.0-1.1$ & $1.1-1.2$ & $1.1-1.6$ & $1.2-1.3$ & $1.4-1.5$ \\
\hline 18 & $1^{\text {st }}$ MesoTiSL & 1.4 & $1.4-1.5$ & $1.3-1.6$ & $1.1-1.3$ & $1.6-2.3$ & $2.0-2.2$ \\
\hline 19 & $2^{\text {nd }}$ MesoTiSL & 0.7 & $0.7-0.8$ & $0.8-0.9$ & $0.6-0.8$ & $0.7-1.0$ & $1.0-1.1$ \\
\hline 20 & MetaTiL & 2.5 & $2.4-2.8$ & $2.8-3.3$ & $2.5-3.3$ & $3.6-4.0$ & $3.8-4.4$ \\
\hline 21 & MetaTiW & 0.9 & $1.0-1.1$ & 1.1 & $1.0-1.2$ & $1.1-1.2$ & $1.3-1.4$ \\
\hline 22 & MetaTiSL & 0.8 & $1.0-1.1$ & $1.0-1.1$ & $1.0-1.2$ & $1.1-1.3$ & $1.2-1.7$ \\
\hline 23 & MetaTaL & 2.9 & 2.9 & $2.8-3.2$ & $2.8-3.1$ & $3.2-3.6$ & $3.0-3.9$ \\
\hline 24 & MetaTa1L & 0.9 & 0.9 & $0.9-1.0$ & $0.9-1.0$ & $1.0-1.3$ & $1.0-1.3$ \\
\hline 25 & MetaTa1W & 0.3 & 0.5 & $0.3-0.5$ & $0.5-0.6$ & $0.5-0.6$ & $0.4-0.7$ \\
\hline 26 & MetaTa5W & 0.1 & 0.1 & 0.1 & 0.2 & $0.1-0.2$ & 0.1 \\
\hline 27 & DDC & 0.8 & 0.9 & 0.7 & $0.9-1.0$ & $1.3-1.6$ & $1.5-1.7$ \\
\hline
\end{tabular}




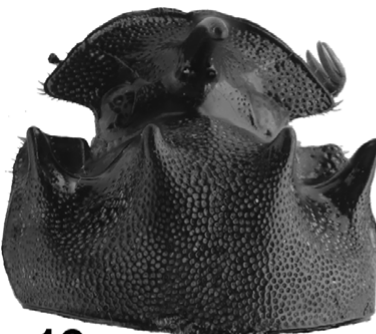

12

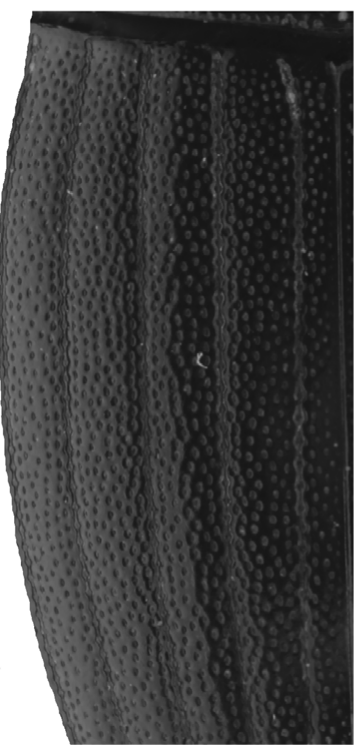

13

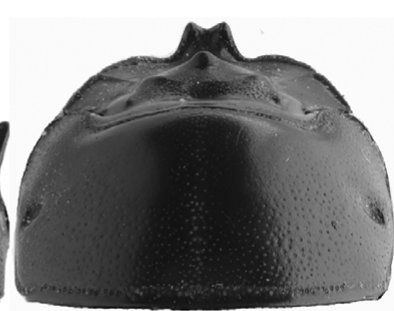

14

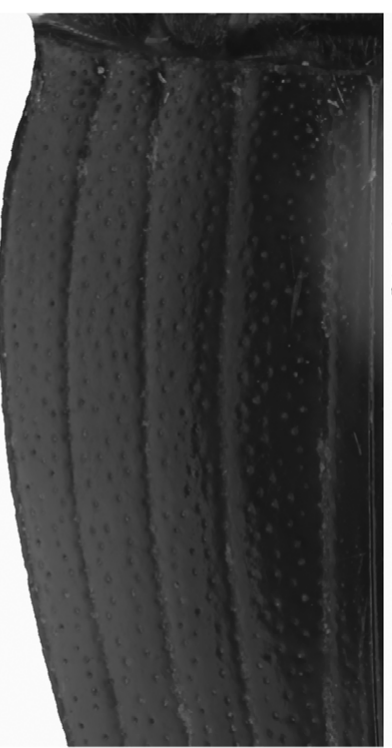

15

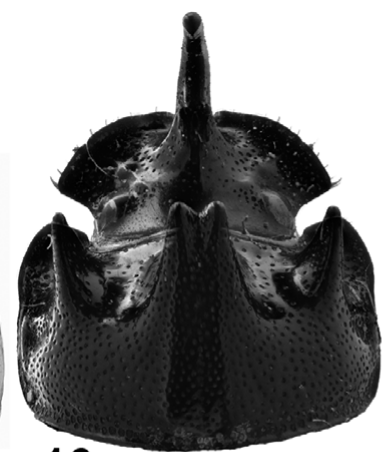

16

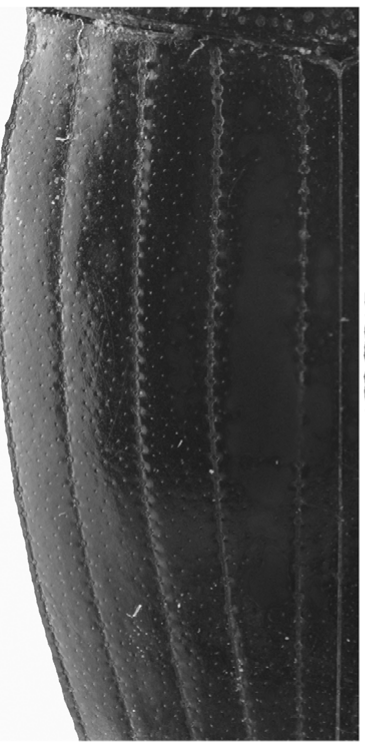

17

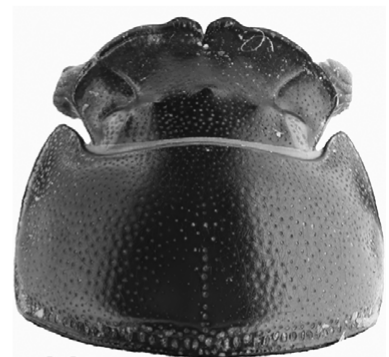

18

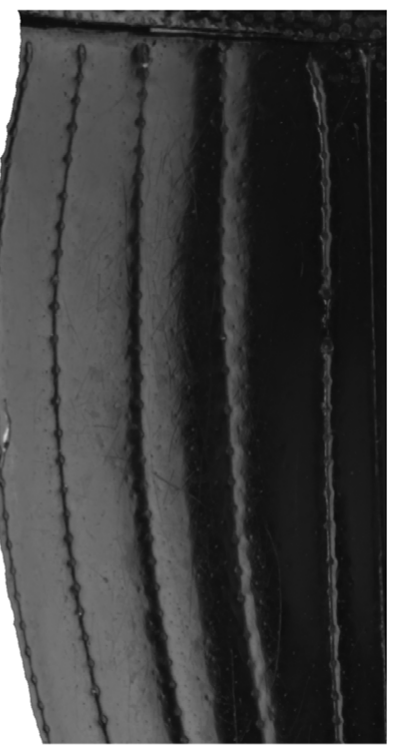

19

Figs 12-19. Pronotal and elytral structures. 12, 13 - Copris caobangensis sp. n., male, pronotum and elytra, showing the armed and excavated pronotum and deeply and densely punctured elytra; $14,15-C$. (Paracopris) punctulatus, male, pronotum and elytra, showing the unarmed pronotum and deeply and sparsely punctured elytra; $16-C$. (Copris) angusticornis, male, showing the armed and excavated pronotum; $17-C$. (C.) punctatus showing the shallowly punctured elytra; $18-C$. (Microcopris) reflexus showing the unarmed pronotum; $19-C$. (M.) propinquus showing the elytra without punctures.

subgenus Microcopris but flat in the new species (Figs 12-19).

Copris caobangensis sp. n. morphologically resembles C. (Copris) vietnamicus Kabakov, 1994 that was described based on a single male specimen collected in Vinhphuc Province. Both species have a similar body shape, in particular, the head and pronotum, and both have dense and deep punctures on the pronotum and interstriae. However, both species differ in the following characters: male cephalic horn is nearly straight in $C$. $(C$.) vietnamicus but curved backwards in the new species. Punctures on interstriae are smaller than pronotal punctures in $C$. $(C$.) vietnamicus, whereas those on interstriae and pronotum are of equal size in the new species. The clypeal apex is more strongly emarginated in $C$. $(C$.) vietnamicus. In addition, $C$. (C.) vietnamicus, with a BoL $14.5 \mathrm{~mm}$ and $\mathrm{BoW} 7.8 \mathrm{~mm}$, is larger than the new species, with BoL 11.8-12 mm and BoW 6.3-6.6 mm. The pronotal median sulcus is smooth in $C$. (C.) vietnamicus but strongly punctate in the new species. For differentiation see also the key below.

Type material. Holotype male and 2 female paratypes. Holotype male at VNUF labelled: "VIETNAM, Caobang Prov., Pia Oac NR, 22 $2^{\circ} 4^{\prime} 3^{\prime \prime} \mathrm{N}$; $105^{\circ} 53^{\prime} 5^{\prime \prime} \mathrm{E}, 1222 \mathrm{~m}$ a.s.l., primary for- est, v.20,2016, Van Bac Bui leg." Two female paratypes (one at NMPC, one at VNUF) labelled: "VIETNAM, Caobang Prov., Pia Oac NR, 22 $34^{\prime} 3^{\prime \prime} \mathrm{N}$; $105^{\circ} 53^{\prime} 5^{\prime \prime} \mathrm{E}, 1214 \mathrm{~m}$ a.s.l., primary forest, v.20,2016, Van Bac Bui leg."

Type locality. Northern Vietnam, Caobang Province, Pia Oac Nature Reserve, 2234' $3^{\prime \prime} \mathrm{N}$; 105 $53^{\prime} 5^{\prime \prime} \mathrm{E}, 1214-1222 \mathrm{~m}$.

Etymology. The specific epithet caobangensis refers to the name of the type locality, Caobang Province, North Vietnam.

Collecting details. All specimens of Copris caobangensis sp. n. were collected in Pia Oac Nature Reserve, Caobang Province, North Vietnam using pitfall traps baited with fresh pig dung. The habitat sampled was primary forest that dominated at an altitude range of 1210-1230 m. Both forest canopy cover and cover of leaf litter layer were $>95 \%$.

\section{Copris (Copris) sonensis sp. $\mathbf{n}$.}

Figs 20-24, 26-32, 35

ZooBank taxon LSID:

BB4A6A84-2F6C-4E28-AE36-BD947F4A3602

Description of holotype male. Total body length 14.7 $\mathrm{mm}$, maximum body width $7.8 \mathrm{~mm}$. Head, pronotum and elytra black and shiny. Mouthparts, maxillary palpi, antennomeres 1-6 reddish brown. Antennal club and setae on legs yellow (Figs 20-24). 


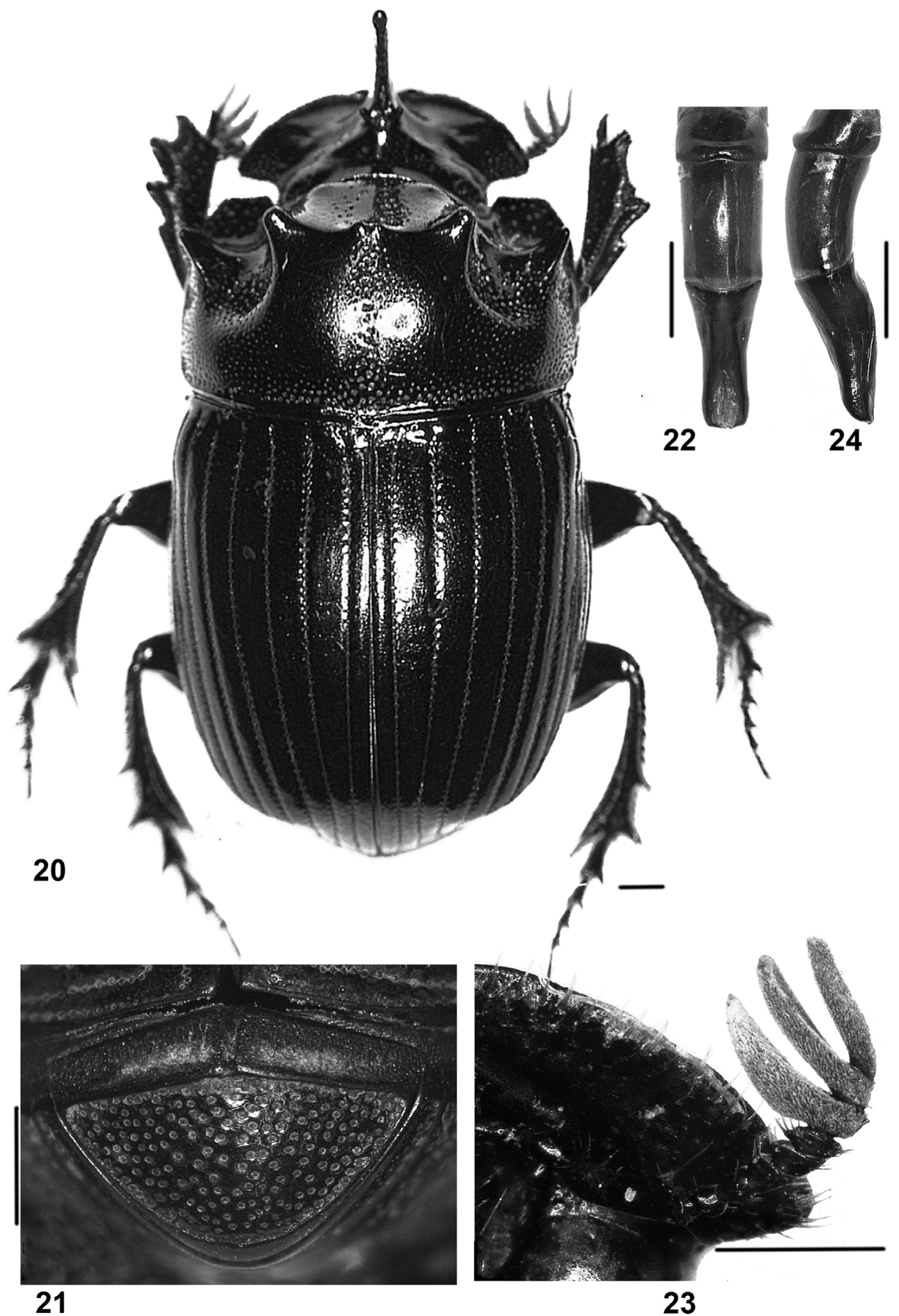

Figs 20-24. Copris (Copris) sonensis sp. n., male holotype. 20 - dorsal habitus; 21 - pygidium; 22 - genitalia dorsal; 23 - left antenna ventral; 24 - genitalia lateral. Scale bars $1 \mathrm{~mm}$.

Head nearly semicircular. Length $2.6 \mathrm{~mm}$, width 5.5 $\mathrm{mm}$. Surface of clypeus relatively smooth; clypeal apex weakly emarginated. Vertex between eyes smooth. Genae sparsely but distinctly punctate. Antenna with 9 antennomeres; antennomere 1 equal in length (approximately $1 \mathrm{~mm}$ ) to antennomeres 2-6 combined and also antennal club. Cephalic horn long $(3.1 \mathrm{~mm})$, curved backwards and with two small but distinct teeth at base; surface of horn quite smooth.

Pronotum length $4.2 \mathrm{~mm}$, width $7.3 \mathrm{~mm}$. Pronotum with sharp anterior declivity. Pronotal disc deeply excavated on each side. Two forward directed prominences present on 


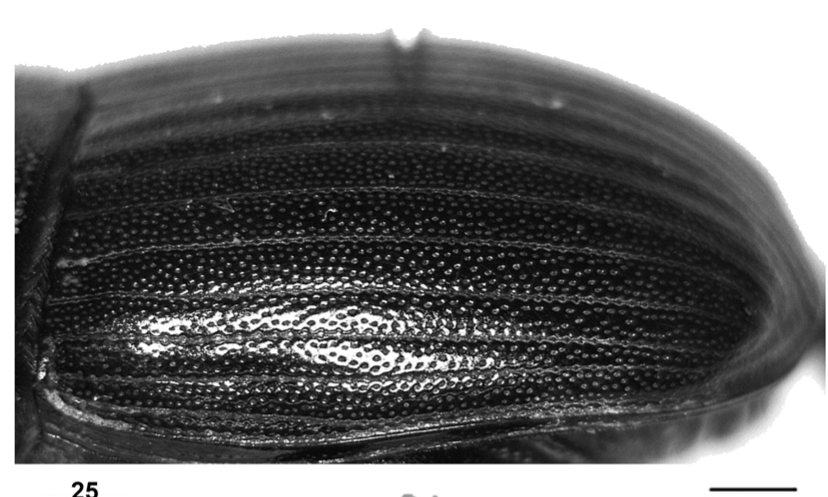

25

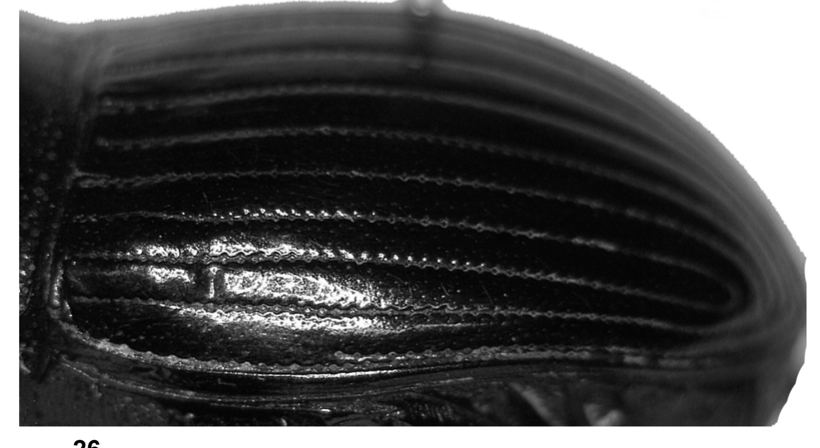

26

Figs 25, 26. Form of elytra, lateral. 25 - Copris caobangensis sp. n. showing the stria 9 complete; $26-C$. (C.) sonensis sp. n. showing the stria 9 incomplete.

dorsal side on anterior part of pronotum. Each lateral angle armed with one sharp and upward directed prominence. Pronotal prominences smooth and impunctate. Pronotal anterolateral angles obtuse; lateral margin slightly curved in front while anterior margin behind genae nearly straight. Almost whole surface of pronotum punctate, except for small areas near prominences smooth; punctures deep, coarse and regular on sides of pronotum, gradually smaller and more irregular on basal half of pronotum and excavations. Vertical anterior surface of prothorax also minutely and irregularly punctate. Pronotum with weak median longitudinal sulcus; sulcus with deep, coarse but irregular punctures.

Elytra with 10 striae; striae 1-8 complete; stria 9 arise on anterior third of elytron; stria 10 complete. All striae deeply, evenly, circularly punctate; distance between two strial punctures twice as large as their diameters. Interstriae slightly convex, shiny and impunctate (Fig. 26).

Mesepimeron and metepisternum flat, rugose, covered by yellow, long and scanty setae.

Meso-metaventral plate smooth, with median distinct groove. Sides strongly, coarsely punctate and sparsely hairy.

Legs. Ventral surface of profemora strongly, coarsely, closely and unequally punctate; punctures becoming denser on anterior half of profemora near base; anterior margin of profemora with yellow, dense and long setae. Protibia (ProTiL $2.8 \mathrm{~mm}$, ProTiW $1.4 \mathrm{~mm}$ ) with four lateral teeth. Protibial spurs (ProTiSL $0.8 \mathrm{~mm}$ ) truncate, distinctly curved inwards near apex, equal in length to protarsomeres 2-4 combined. Protarsomere 1 and 5 equal in length. Mesofemora deeply, coarsely punctate on ventral side; punctures becoming sparser and shallower toward anterior half of mesofemoral near base. Mesotibia (MesoTiL 2.8 $\mathrm{mm}$, MesoTiW $1.1 \mathrm{~mm}, 1^{\text {st }}$ MesoTiSL $1.3 \mathrm{~mm}, 2^{\text {nd }}$ MesoTiSL $0.9 \mathrm{~mm}$ ) broadly dilated at posterior end. Deep, coarse and distinct punctures also present on metafemora, becoming denser on third anterior part of metafemora. Metatibia (MetaTiL $3.1 \mathrm{~mm}$, MetaTiW $1.1 \mathrm{~mm}$, MetaTiSL $1.0 \mathrm{~mm}$ ) with strongly transverse outer carina. Mesotarsi and metatarsi short, and both with yellow scanty setae.

Abdomen. Pygidium length $1.7 \mathrm{~mm}$, width $3.2 \mathrm{~mm}$, with complete margin. Surface slightly convex, and deeply, equally punctate. Punctures on pygidium circular and very close, their distance apart equals their diameter. Abdominal ventrites deeply and closely punctate; ventrites becoming extremely narrow in middle.

Aedeagus. Phallobase $1.8 \mathrm{~mm}$ in length with large dorsal lobes. Parameres shorter than phallobase, approximately $1.7 \mathrm{~mm}$ in length. Broad angle more than $140^{\circ}$ formed by phallobase and parameres.

Sexual dimorphism. Females differ from the male holotype in the following characters: Head armed with one straight, short horn; horn apex strongly excavated. Clypeal apex more strongly emarginated. Pronotum unarmed and not excavated on each side. Pronotal disc and frons more densely punctate (Figs 27-31).

Variation. Body length $13.3-15.2 \mathrm{~mm}$, body width 7.3-8.4 mm $(\mathrm{n}=9)$. The four male paratypes are smaller, compared to the holotype, have smaller prominences and excavations on the pronotum but similar in the remaining characters. A large male paratype in the material examined is morphologically similar to the holotype. There are no significant differences in pronotal structures in females. Other characters of females are consistent within populations.

Differential diagnosis. Copris sonensis sp. n. can be placed in the nominotypical subgenus with the following characters: Pronotum with sharp anterior declivity, armed; interstriae sparsely and minutely punctate; front angles of pronotum not excavated on ventral side. The new species, compared to species within the subgenus Copris from Vietnam and adjacent countries, has many similarities to $C$. (C.) zhangi Ochi, Kon \& Bai, 2009 from China, C. (C.) tripartitus Waterhouse, 1875 from China, Taiwan, Korea and Japan and C. (C.) sarpedon Harold, 1868 from Thailand, Kashmir, Assam, Nepal, but has a different clypeal surface, cephalic horn structure and pronotum. The clypeus is smooth in the new species but deeply punctate in C. zhangi, C. tripartitus and C. sarpedon. In addition, C. sonensis sp. n. typically bears two distinct teeth at the base of the male cephalic horn while $C$. tripartitus and $C$. sarpedon have two minute, indistinct teeth at the base. Pronotal punctures are deeper, denser and more evenly distributed in C. sarpedon (Figs 32-34). Characters on the male pronotal structures clearly differentiate $C$. sonensis sp. n. from $C$. zhangi. In $C$. sonensis sp. n., pronotal disc with six prominences, the median two are small and noticeably contiguous, whereas in C. zhangi, the median two prominences not touching or noticeably contiguous. 

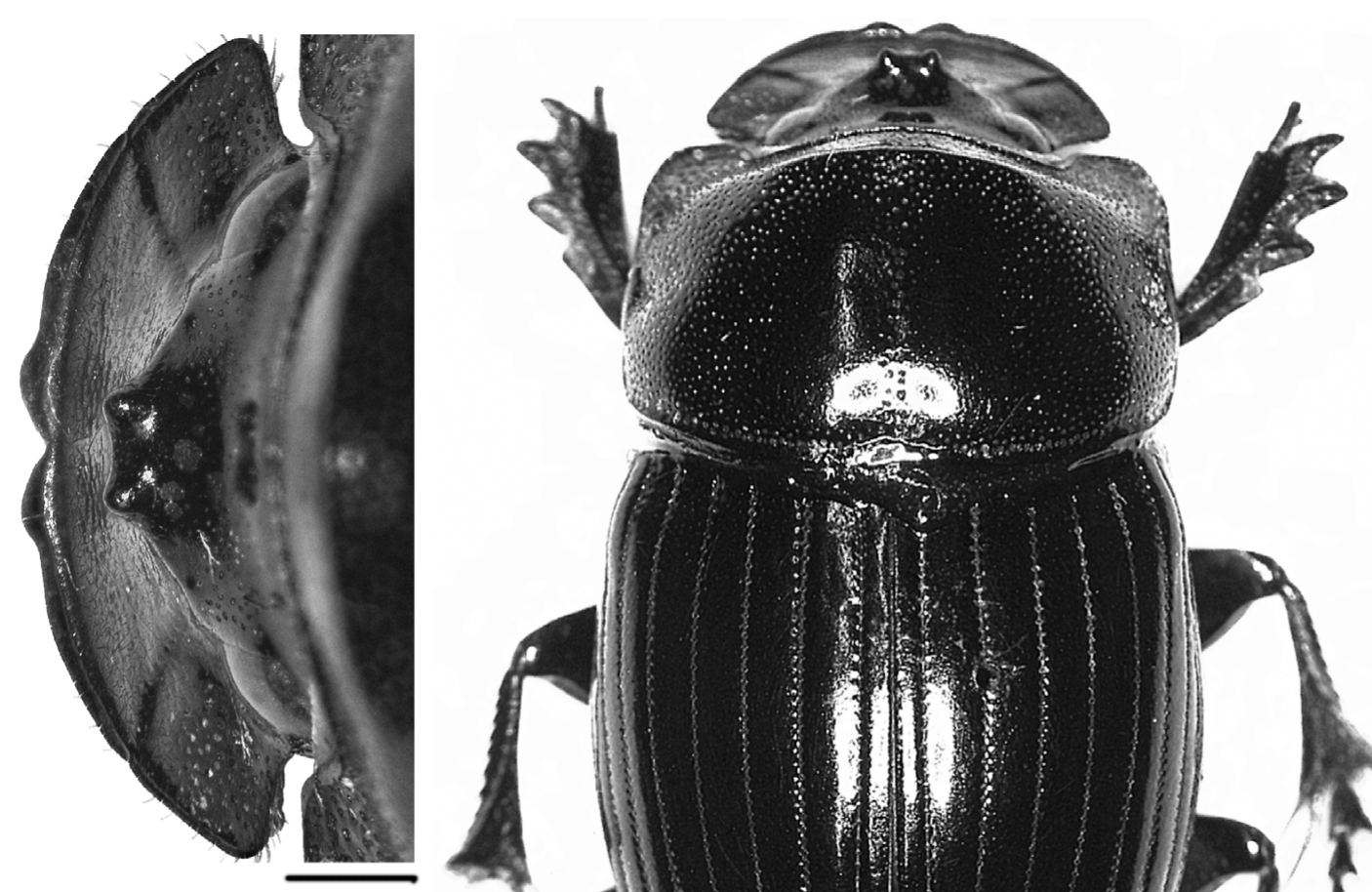

27
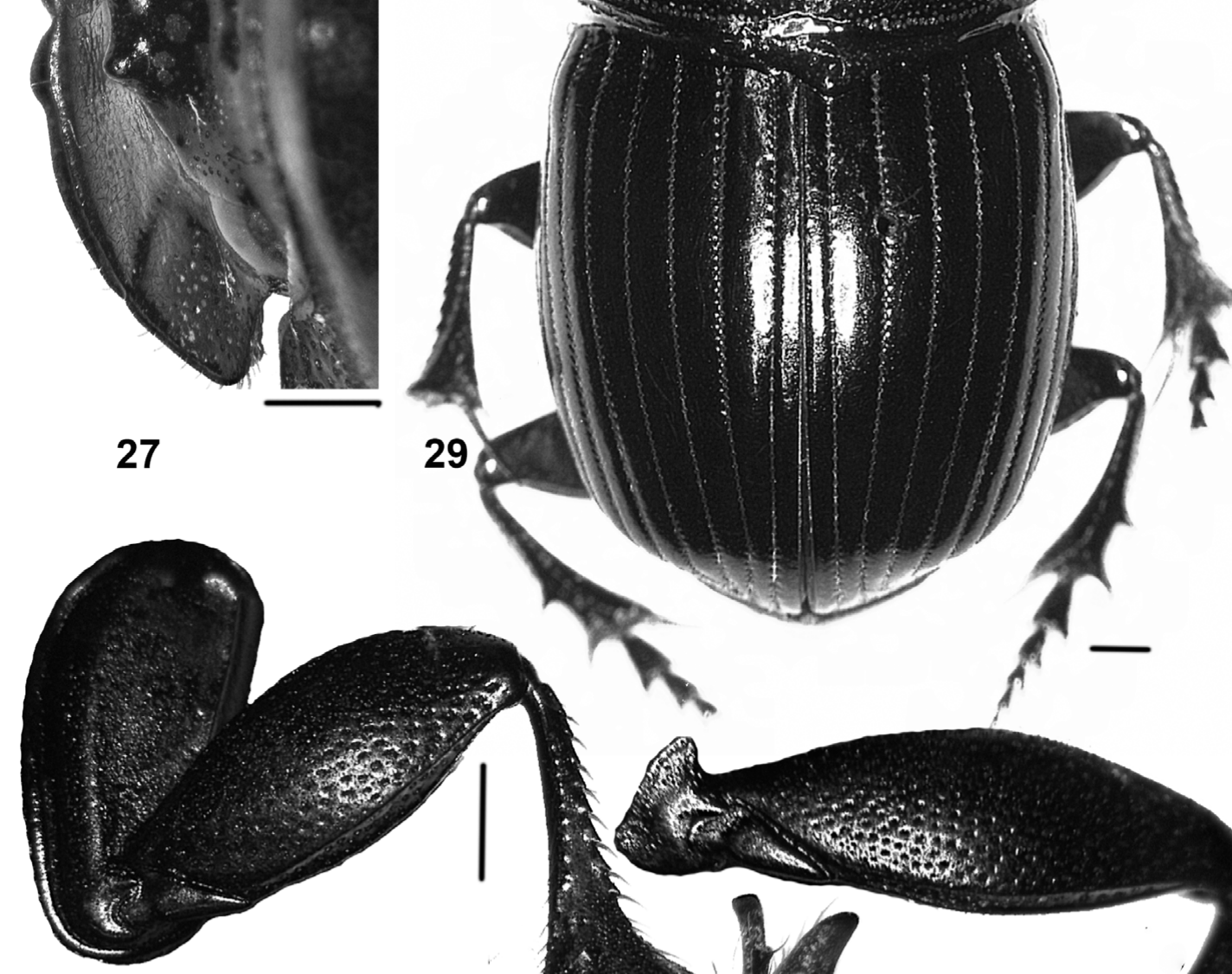

28

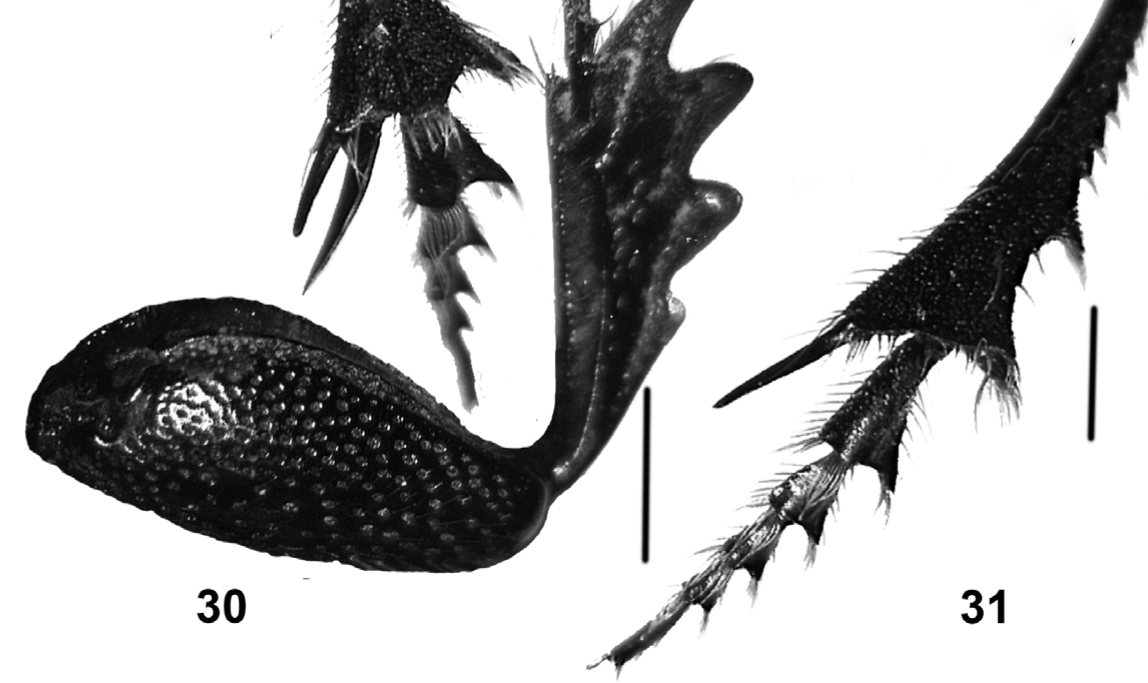

Figs 27-31. Copris (Copris) sonensis sp. n., female paratype. 27 - horn, 28 - left mesothoracic leg ventral; 29 - dorsal habitus, 30 - left prothoracic leg ventral; 31 - left metathoracic leg ventral. Scale bars $1 \mathrm{~mm}$.

Copris sonensis sp. $\mathrm{n}$. is also similar to C. (C.) cambodiensis Ochi, Kon \& Kawahara, 2008 from Phumi Kalai Thum (Cambodia) in terms of body shape, especially the structure of the head, pronotum and legs. However, it can be distinguished from C. cambodiensis by the structure of the elytral striae. The new species has an incomplete stria 


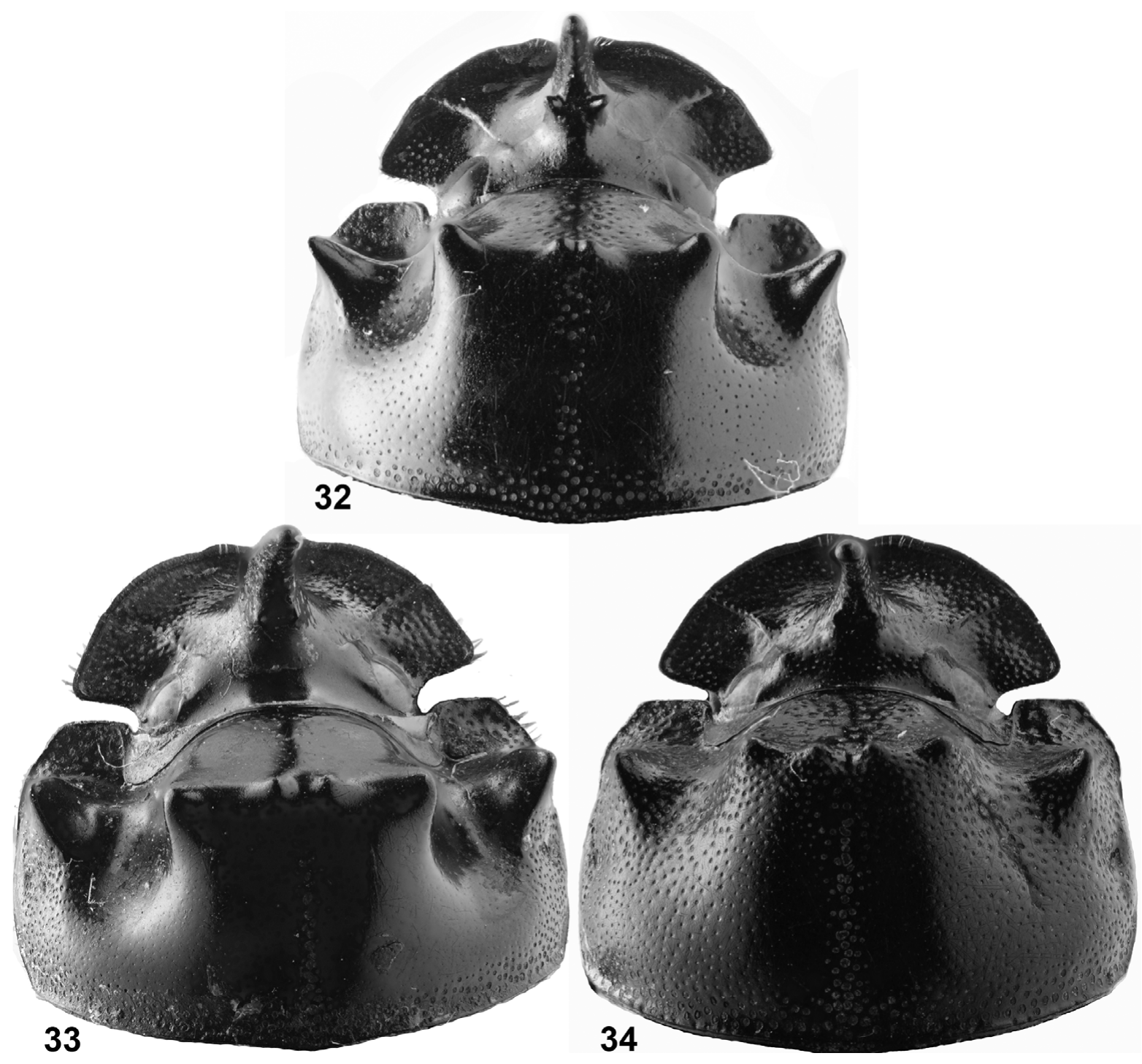

Figs 32-34. Form of horns and pronotal structures of males. 32 - Copris (Copris) sonensis sp. n.; $33-$ C. (C.) tripartitus; $34-$ C. (C.) sarpedon.

9 and two separate striae 9 and 10 (Fig. 26), while C. cambodiensis has an incomplete stria 8 and the basal halves of striae 9 and 10 merge. In addition, the new species with BoL 13.3-15.2 mm, BoW 7.3-8.4 mm is smaller than $C$. cambodiensis with BoL 17.0-18.1 mm, BoW 9.0-9.6 mm.

Small males of the new species are similar to $C$. $(C$.) sinicus Hope, 1842 but can be distinguished by the clypeal apex. All small males of the new species examined have a widely and shallowly emarginated clypeal apex while C. sinicus has a narrowly and deeply emarginated clypeal apex (Figs 35, 36). The clypeus is more deeply punctate in C. sinicus. The molecular analysis indicated a divergence between $C$. sonensis sp. n. and C. sinicus of $8.9-9 \%$ in the COXI sequence.

Type material. Holotype male, 5 male paratypes, and 2 female paratypes. Holotype male at VNUF labelled: "VIETNAM, Thanhhoa Prov., Pu Luong NR, Son village, 20²8'53"N; $105^{\circ} 14^{\prime} 42^{\prime \prime} \mathrm{E}, 853 \mathrm{~m}$ a.s.1., secondary forest, 10-25.iv.2016, Van Bac Bui leg." Paratypes: Male at VNUF: "VIETNAM, Thanhhoa Prov., Pu Luong NR, Son village, 20²8'54"N; 105'14'43"E, 875 m a.s.1., secondary forest, 10-25.iv.2016, Van Bac Bui leg." Male at VNUF: "VIETNAM, Thanhhoa Prov., Pu Luong NR, Son vil- lage, $20^{\circ} 28^{\prime} 54^{\prime \prime} \mathrm{N} ; 105^{\circ} 14^{\prime} 41^{\prime \prime} \mathrm{E}, 867 \mathrm{~m}$ a.s.1., secondary forest, 10-25.iv.2016, Van Bac Bui leg." Female at VNUF: "VIETNAM, Thanhhoa Prov., Pu Luong NR, Son village, 20²8'51"N; $105^{\circ} 14^{\prime} 44^{\prime \prime} \mathrm{E}, 860 \mathrm{~m}$ a.s.1., secondary forest, 10-25.iv.2016, Van Bac Bui leg." Female at VNUF: "VIETNAM, Thanhhoa Prov.,

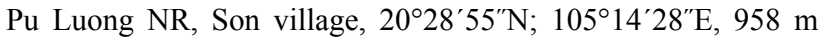
a.s.1., primary forest, 10-25.iv.2016, Van Bac Bui leg." Male at NMPC: "VIETNAM, Thanhhoa Prov., Pu Luong NR, Son village, $20^{\circ} 28^{\prime} 53^{\prime \prime} \mathrm{N} ; 105^{\circ} 14^{\prime} 41^{\prime \prime} \mathrm{E}, 856 \mathrm{~m}$ a.s.l., secondary forest, 10-25.iv.2016, Van Bac Bui leg." Male at RMNH: "VIETNAM, Thanhhoa Prov., Pu Luong NR, Son village, 20²8'53"N; $105^{\circ} 14^{\prime} 42^{\prime \prime} \mathrm{E}, 853 \mathrm{~m}$ a.s.1., secondary forest, 10-25.v.2016, Van Bac Bui leg." Male at PLNR: "VIETNAM, Thanhhoa Prov., Pu Luong NR, Son village, $20^{\circ} 28^{\prime} 52^{\prime \prime N}$; $105^{\circ} 14^{\prime} 43^{\prime \prime} \mathrm{E}, 866 \mathrm{~m}$ a.s.l., secondary forest, 10.-25.v.2016, Van Bac Bui leg."

Type locality. Central Vietnam, Thanhhoa Province, Pu Luong Nature Reserve, Son Ba Muoi area, Son village, $20^{\circ} 28^{\prime} 53^{\prime \prime} \mathrm{N}$; $105^{\circ} 14^{\prime} 42^{\prime \prime} \mathrm{E}, 850-960 \mathrm{~m}$.

Etymology. The specific epithet sonensis refers to the name of the type locality, Son village, Son Ba Muoi area, Thanhhoa Province, central Vietnam.

Collecting details. During intensive surveys of dung beetle communities inhabiting ecosystems on limestone bedrock in the two nature reserves, 12 specimens of $C$. sonensis sp. n. were col- 


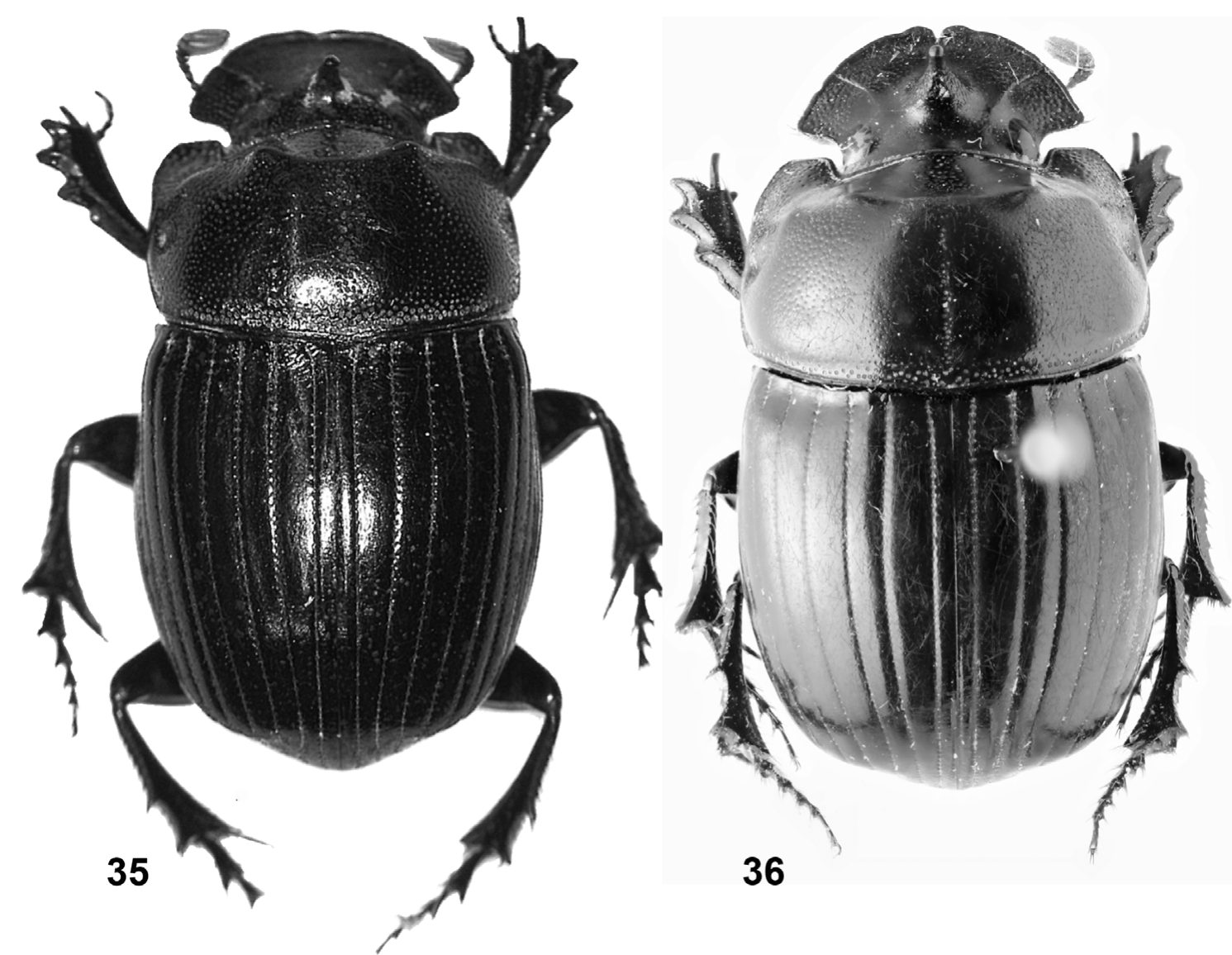

Figs 35, 36. Dorsal habitus. 35 - Copris (Copris) sonensis sp. n., small male, showing clypeal apex with wide and shallow emargination; $36-$ C. (C.) sinicus, male, showing clypeal apex with narrow and deep emargination.

lected in Pu Luong Nature Reserve. Habitats of C. sonensis sp. n. comprised primary forest and secondary forest that were characterized by a complex vertical structure with various forest layers, at an altitudinal range from $850-960 \mathrm{~m}$ and forest canopy cover ranging from 75 to $100 \%$. No specimens of C. sonensis sp. n. were found in meadows during our surveys.

\section{Copris (Copris) szechouanicus Balthasar, 1958}

Figs 47, 67, 73

Comments. This species is here recorded for the first time from Vietnam (Caobang Province and Thanhhoa Province). Based on 18 measured specimens, we provide additional measurements of this species (Table 2).

Type material examined. Holotype male, allotype female, 6 male paratypes and 1 female paratype in NMPC. Holotype male: "Kuatun [= nowadays Guadun], Fukien, China, 15.06.46, leg. Tschung-Sen." Allotype female: "Giufu Shan [= nowadays Jinfo Shan], Szechuan, 1500-2000 m, Reitter E." Two male paratypes: "Kuatun, $2300 \mathrm{~m}, 27.40^{\circ} \mathrm{N} ; 117.40^{\circ} \mathrm{E}$, L.J. Klapperich, 15.5.1938, (Fukien)." Two male paratypes: "Kwangtseh-Fukien, J. Klapperich, 8.10.1937.” One male paratype: "Tatsienlu, Yüling Süd, Szechuan China." One female paratype: "Kuatun, Fukien, China, 15.6.46, leg. Tschung-Sen." One male paratype: "Nördl Szechuan, China, Kwanhsien Em. Reitter."

Additional material examined. 254 specimens (VNUF), all from Vietnam, baited pitfall traps, B. V. Bac leg. 234 specimens, Thanhhoa Prov., Pu Luong NR, 752-965 m, 20²8'54"-29'11"N; $105^{\circ} 14^{\prime} 22-41^{\prime \prime E}, 5 .-20 . i v .2016 ; 20$ specimens, Caobang Prov., Pia Oac NR, 1154-1223 m, 22³4'3-24"N; 105 52'48'-53'3"E, 5.-20.v.2016.
Distribution and ecology. Copris (C.) szechouanicus has hitherto been known from China (Sichuan Province and Fujian Province) (e.g., Balthasar, 1963). In Vietnam it was found in both Pia Oac and Pu Luong NR with a higher number of individuals collected in the latter with 6 individuals/trap, compared with $<1$ individual/trap in the former. Copris szechouanicus showed a strong preference for forest with $6.6 \pm 1.1$ and $8.9 \pm 1.6$ individuals/trap in primary and secondary forest, compared to $1.9 \pm 0.4$ individuals/trap in meadows $(F=10.19, p<0.001)$ (Fig. 37).

\section{Updated checklist of species of Copris in Vietnam}

Balthasar $(1939,1958,1963)$ divided Copris species occurring in the Oriental and Palearctic Regions into three subgenera: Copris, Paracopris and Microcopris, based on differences in the elytral and pronotal structures. This classification was used for the Southeast Asian species by Kabakov \& Napolov (1999), Hanboonsong et al. (2003) and Ochi et al. (2004, 2008, 2009). Subsequently, the subgenus Sinocopris Ochi, 2009 was erected. Using Balthasar's (1963) classification, we can place in subgenera almost all Vietnamese species, except the new species $C$. caobangensis sp. n., whose morphological characters do not fit any of the known subgenera in South East Asia.

The checklist of Vietnamese Copris below was mainly updated from Balthasar (1963), Kabakov \& Napolov (1999), Hanboonsong et al. (2003), Ochi \& Kon (2004) and Heyes et al. (2009). For the six species recorded in our 


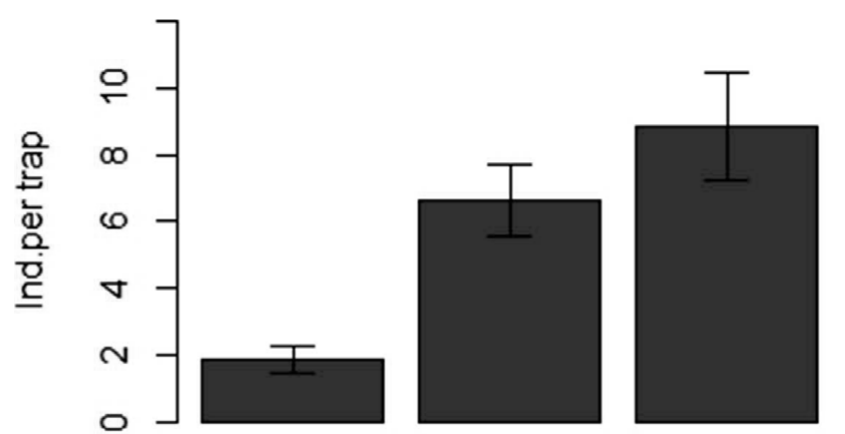

Meadow Primary F. Secondary F

Fig. 37. Mean ( \pm SE) numbers of Copris (C.) szechouanicus collected per trap-day in three areas with different land use intensities ( $F-$ forest).

field surveys we provide collecting details and their habitat preferences in limestone ecosystems.

\section{Subgenus Copris Geoffroy, 1762}

1. Copris (Copris) angusticornis Arrow, 1933. Distribution in Vietnam: North Vietnam (Caobang, Langson, Sonla provinces). Habitat recorded: montane tropical forest, 600-1500 m a.s.1. (Balthasar, 1963; Kabakov \& Napolov, 1999).

Elsewhere: China and Thailand (Balthasar, 1963; Hanboonsong et al., 2003; Kabakov \& Shokhin, 2014).

2. Copris (Copris) carinicus Gillet, 1910. Distribution in Vietnam: North Vietnam (Tuyenquang, Thainguyen, Backan, Vinhphuc, Sonla, Dienbien provinces), Central Vietnam (Thanhhoa Province) and South Vietnam (Gialai, Kontum provinces). Habitats recorded: primary tropical rainforest, secondary tropical forest and secondary savannah, 10-1800 m a.s.l. (Kabakov \& Napolov, 1999; Heyes et al., 2009).

Elsewhere: India, Myanmar, Thailand and China (Balthasar, 1963; Hanboonsong et al., 2003; Boonrotpong et al., 2004; Kabakov \& Shokhin, 2014).

3. Copris (Copris) confucius Harold, 1877. Distribution in Vietnam: Thanhhoa Province, 750-950 m a.s.l., primary forest (15 individuals), secondary forest (4 individuals) and meadows (5 individuals). Outside the region studied, it was recorded widely in North Vietnam (Hagiang, Tuyenquang, Thainguyen, Vinhphuc, Quangninh, Laocai, Sonla provinces) and Central Vietnam (Nghean, Quangbinh provinces) (Balthasar, 1963; Kabakov \& Napolov, 1999).

Elsewhere: Malaysia, Myanmar, Thailand, Laos, Cambodia and China (Balthasar, 1963; Hanboonsong et al., 2003; Kabakov \& Shokhin, 2014).

4. Copris (Copris) corpulentus Gillet, 1910. Distribution in Vietnam: North Vietnam (Hagiang, Tuyenquang, Thainguyen, Vinhphuc, Quangninh, Sonla provinces) and Central Vietnam (Thanhhoa, Nghean, Hatinh, Quangbinh provinces). Habitats recorded: semiarid semi-deciduous tropical forest, montane tropical forest, secondary tropical forest and secondary savannah, 100-1600 m a.s.l. (Balthasar, 1963; Kabakov \& Napolov, 1999).

Elsewhere: India, Myanmar, Thailand, Laos and China (Balthasar, 1963; Hanboonsong et al., 2003; Sewak, 2009; Kabakov \& Shokhin, 2014).

5. Copris (Copris) iris Sharp, 1875. Distribution in Vietnam: this species occurs in Vietnam according to Balthasar (1963) and Hanboonsong et al. (2003), but there is no locality data recorded for it.

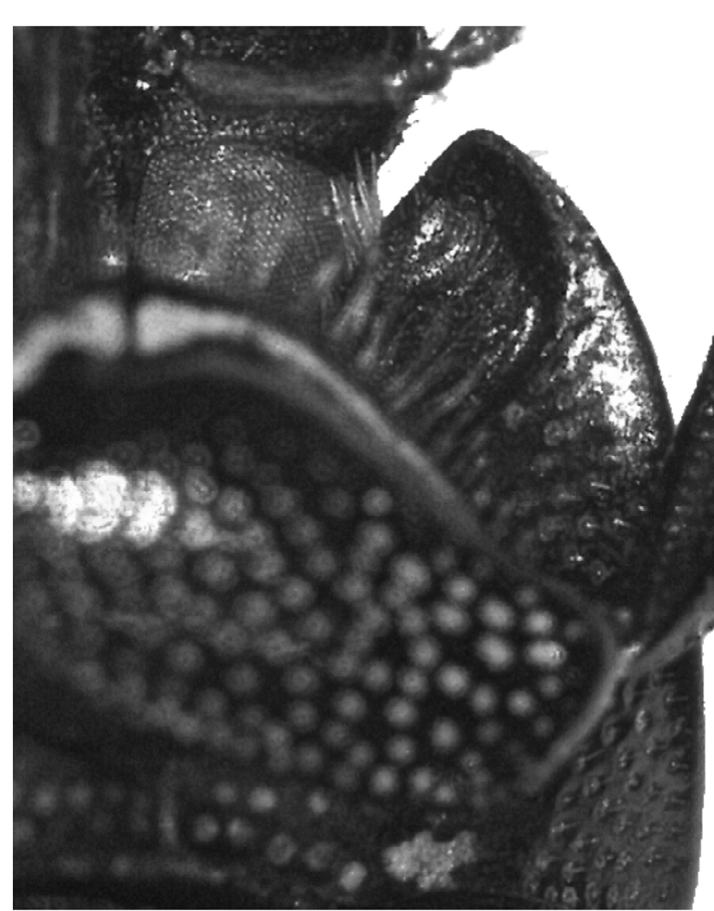

38

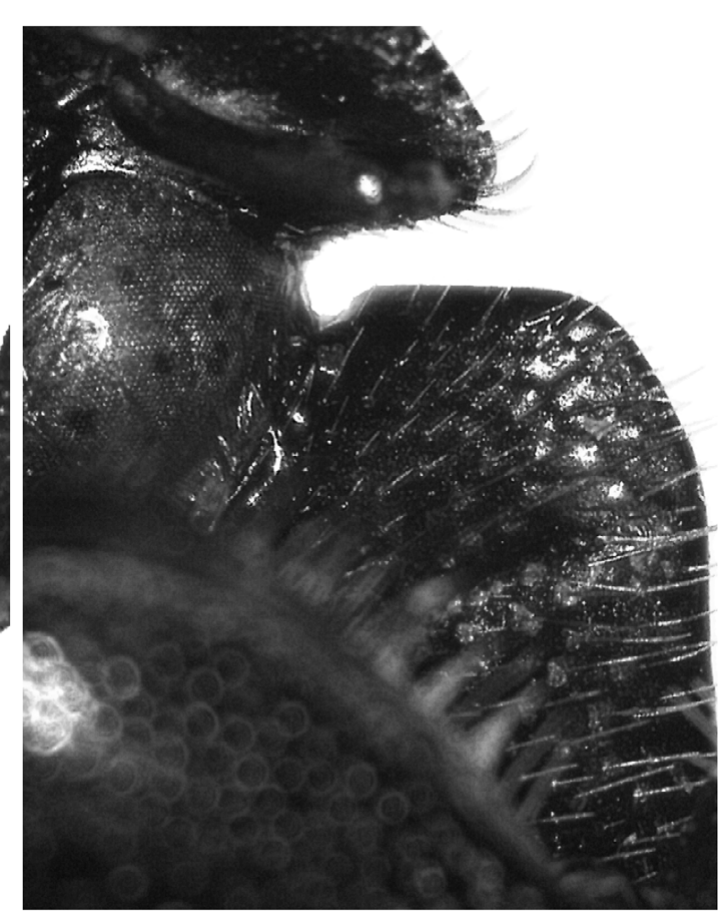

39

Figs 38, 39. Front angles of prothorax in ventral view. 38 - Copris (Microcopris) propinquus showing the angle at the front of prothorax with deep excavation; $39-C$. (Copris) magicus showing the angle at the front of prothorax without excavation. 

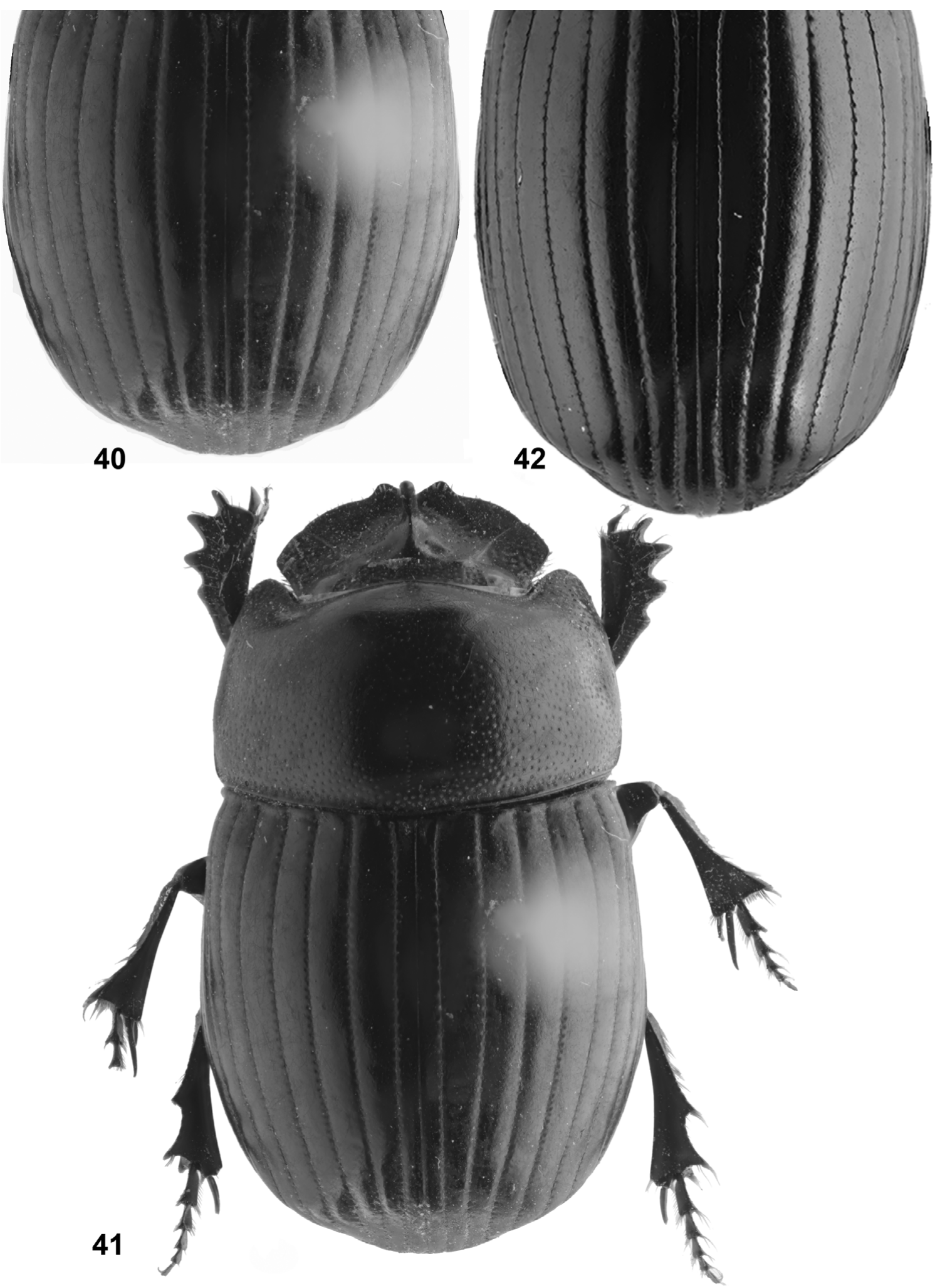

Figs 40-42. Dorsal habitus and elytral characters. 40, 41 - Copris (Microcopris) doriae, male, elytra and dorsal habitus; 42 - C. (M.) propinquus, elytra.

Elsewhere: India, Malaysia, Myanmar, Laos, Thailand and China (Balthasar, 1963; Hanboonsong et al., 2003; Sewak, 2009).

6. Copris (Copris) magicus Harold, 1881. Distribution in Vietnam: According to Kabakov \& Napolov (1999), this species occurs in Sapa (1700-2000 m a.s.1.) and Fansipan (2000-2600 m a.s.1.) (Laocai Province, northern Vietnam) and Muongxen (800-1100 m a.s.l.) (Nghean Province, central Vietnam), in montane tropical forest. In our study, this species was newly recorded for Caobang Province 


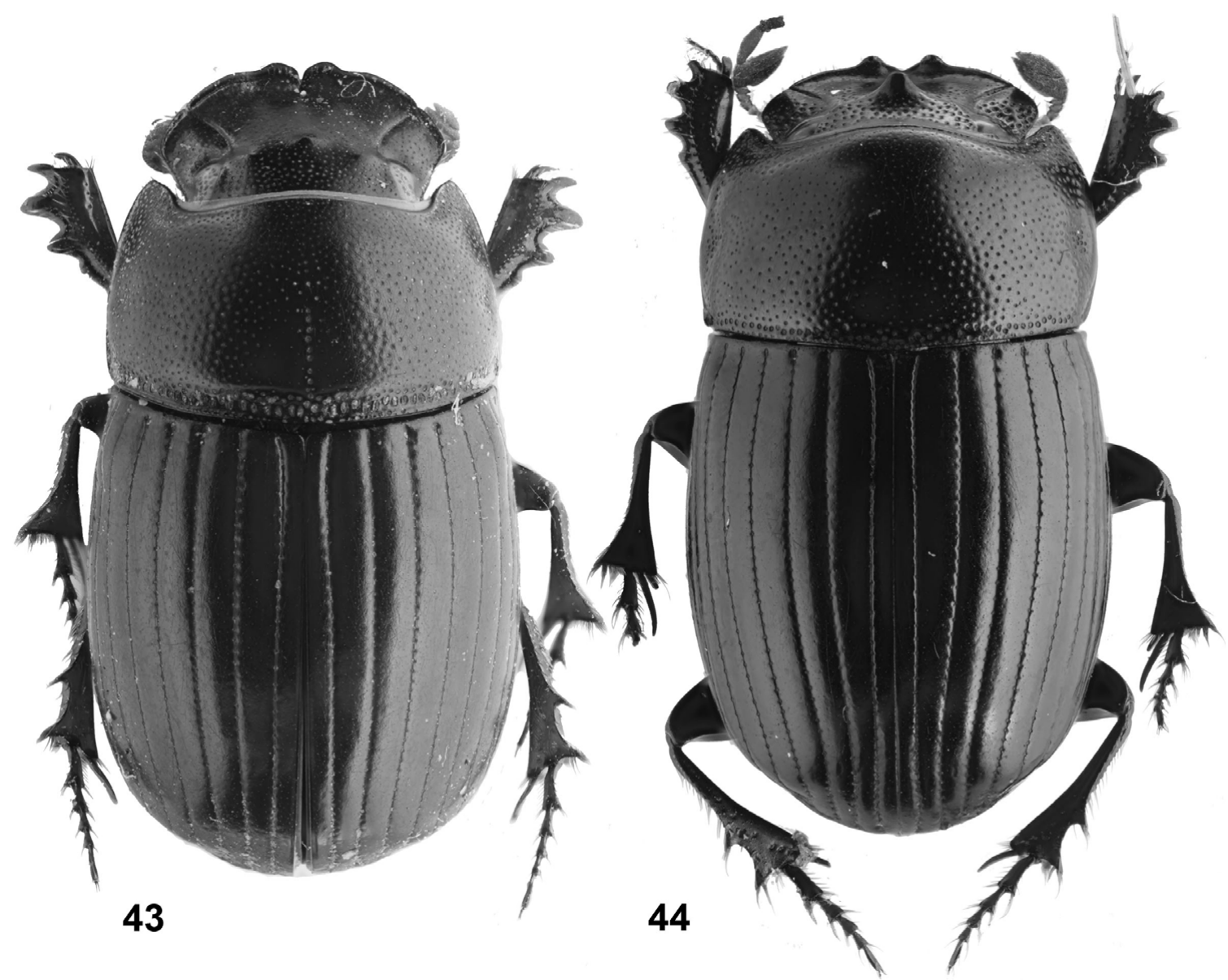

Figs 43, 44. Dorsal habitus. 43 - Copris (Microcopris) reflexus; 44 - C. (M.) propinquus, male.

(northern Vietnam), 1150-1220 m a.s.1., meadows (16 individuals) and primary forest (1 individual).

Elsewhere: India, Laos, Myanmar, Thailand and China (Balthasar, 1963; Hanboonsong et al., 2003; Kabakov \& Shokhin, 2014).

7. Copris (Copris) nevinsoni Waterhouse, 1891. Distribution in Vietnam: Binhduong Province (South Vietnam). Habitat recorded: semiarid semi-deciduous tropical forest (Balthasar, 1963; Kabakov \& Napolov, 1999).

Elsewhere: Malaysia, Laos and Thailand (Balthasar, 1963; Hanboonsong et al., 2003).

8. Copris (Copris) numa Lansberge, 1886. Distribution in Vietnam: Nghean Province (Central Vietnam). Habitats recorded: semiarid semi-deciduous tropical forest and montane tropical forest, 300-1000 m a.s.1. (Kabakov \& Napolov, 1999).

Elsewhere: India, Myanmar, Malaysia, Indonesia and Thailand (Balthasar, 1963; Hanboonsong et al., 2003; Sewak, 2009).

9. Copris (Copris) repertus Walker, 1858. Distribution in Vietnam: Nghean Province (Central Vietnam). Habitats recorded: montane tropical forest, secondary tropical forest and secondary savannah, 300-1100 m a.s.l. (Kabakov \& Napolov, 1999).

Elsewhere: India, Sri Lanka and China (Balthasar, 1963; Sabu et al., 2006; Sewak, 2009; Kabakov \& Shokhin, 2014).

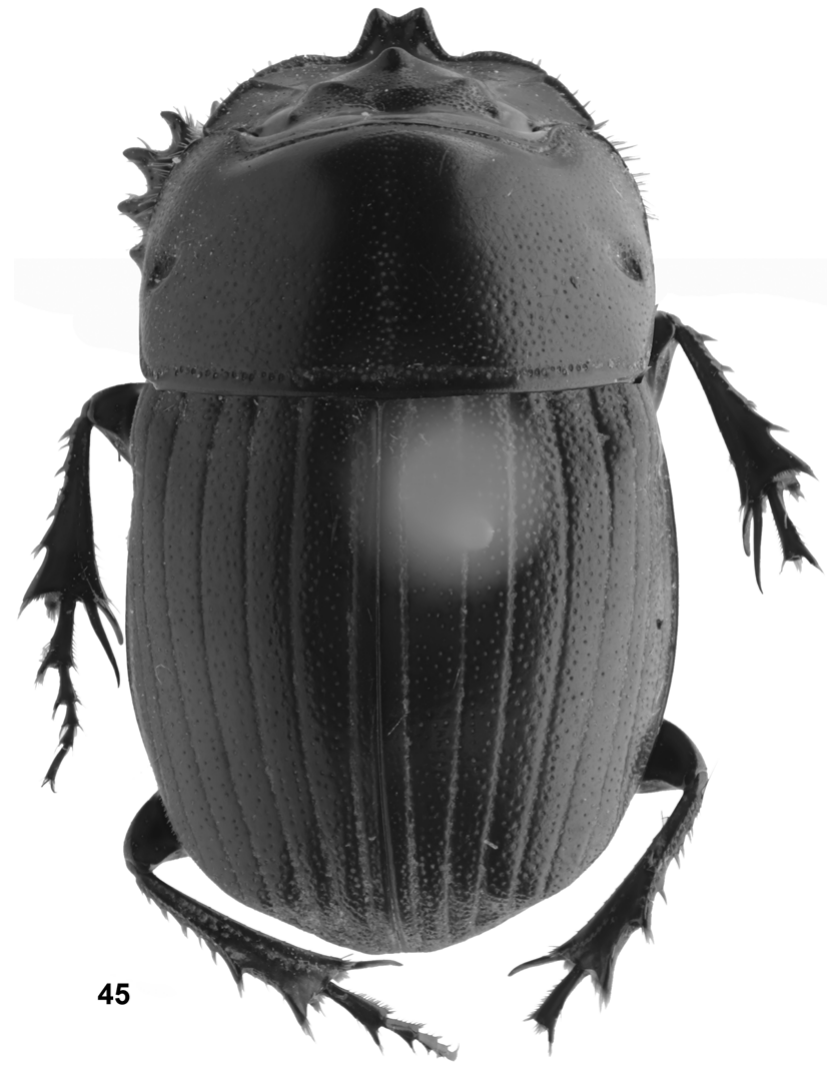

Fig. 45. Copris (Paracopris) punctulatus, dorsal habitus, male. 


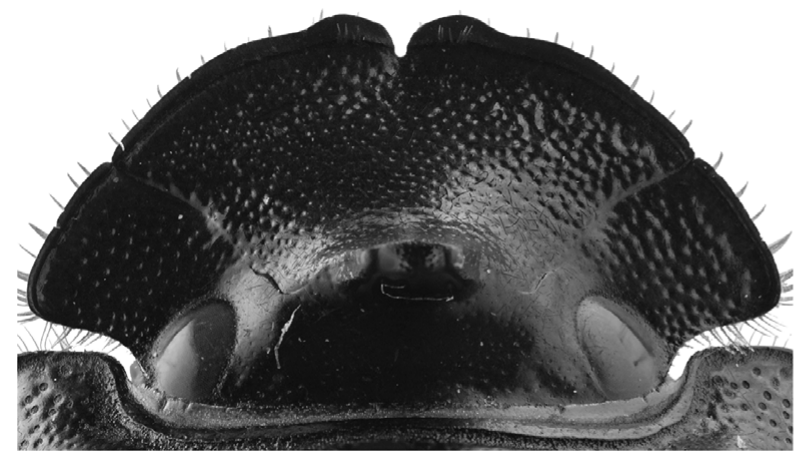

46

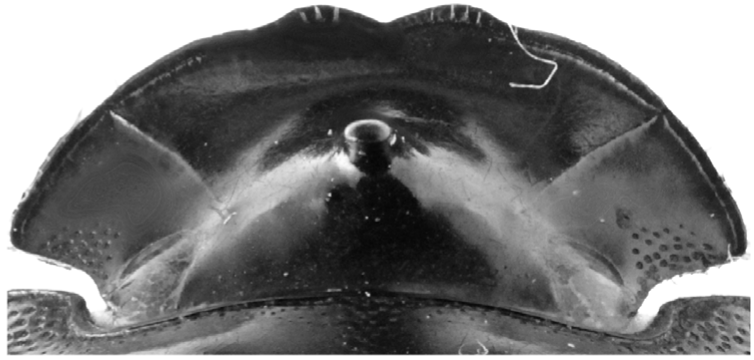

47

Figs 46, 47. Clypeal surfaces. 46 - Copris (Copris) sinicus showing clypeus with deep and distinct punctures; 47 - C. (C.) szechouanicus showing clypeus without punctures.

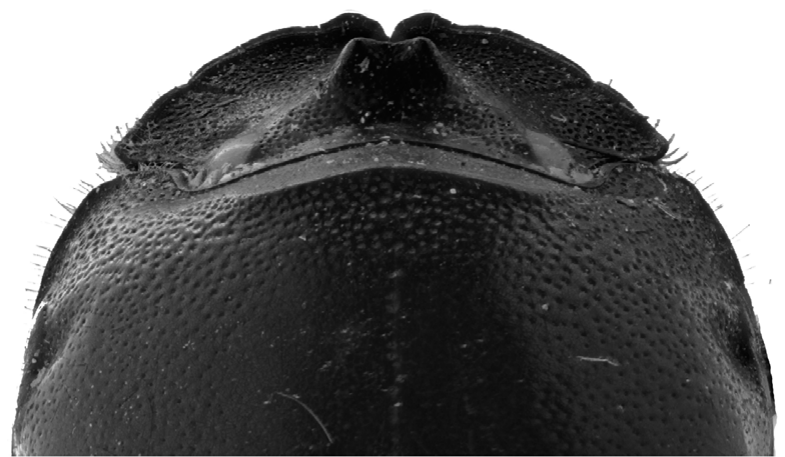

48

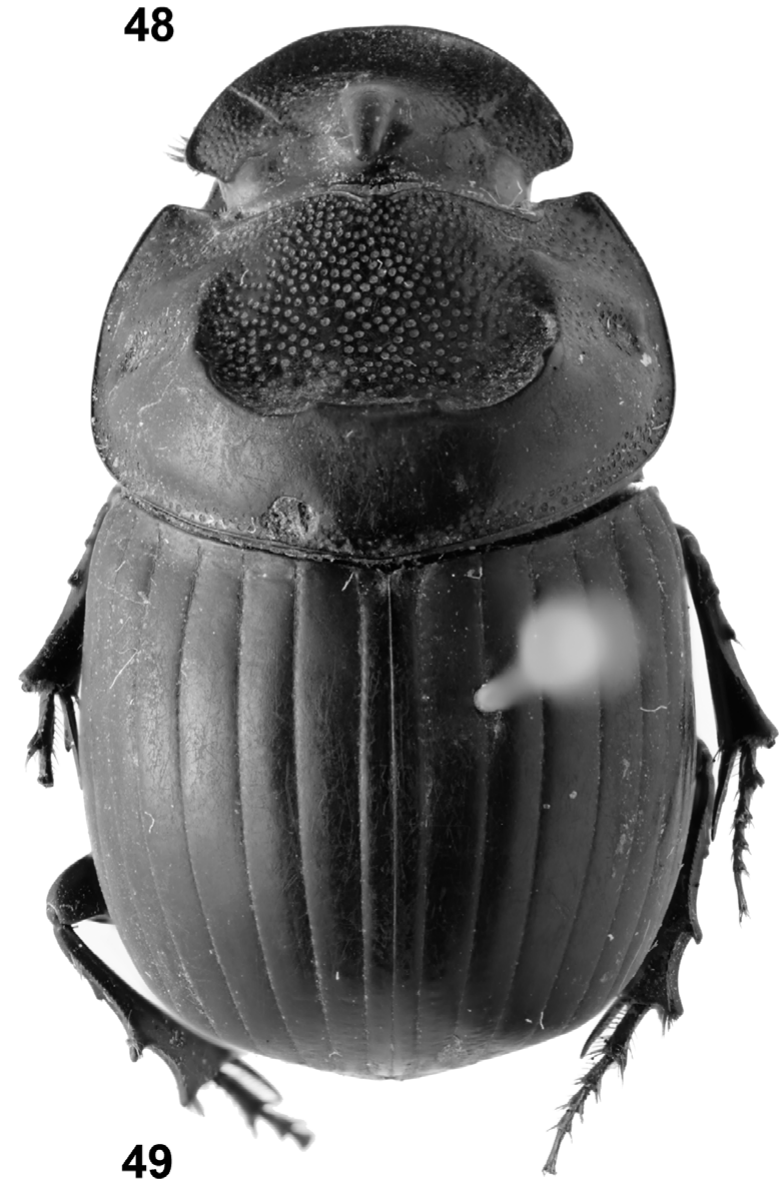

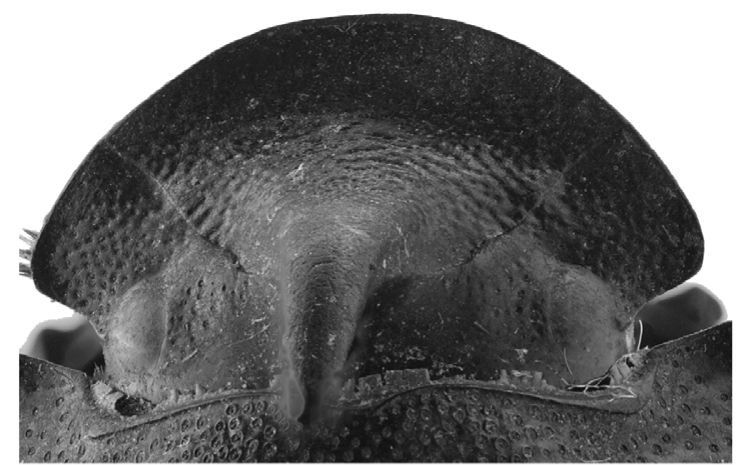

50

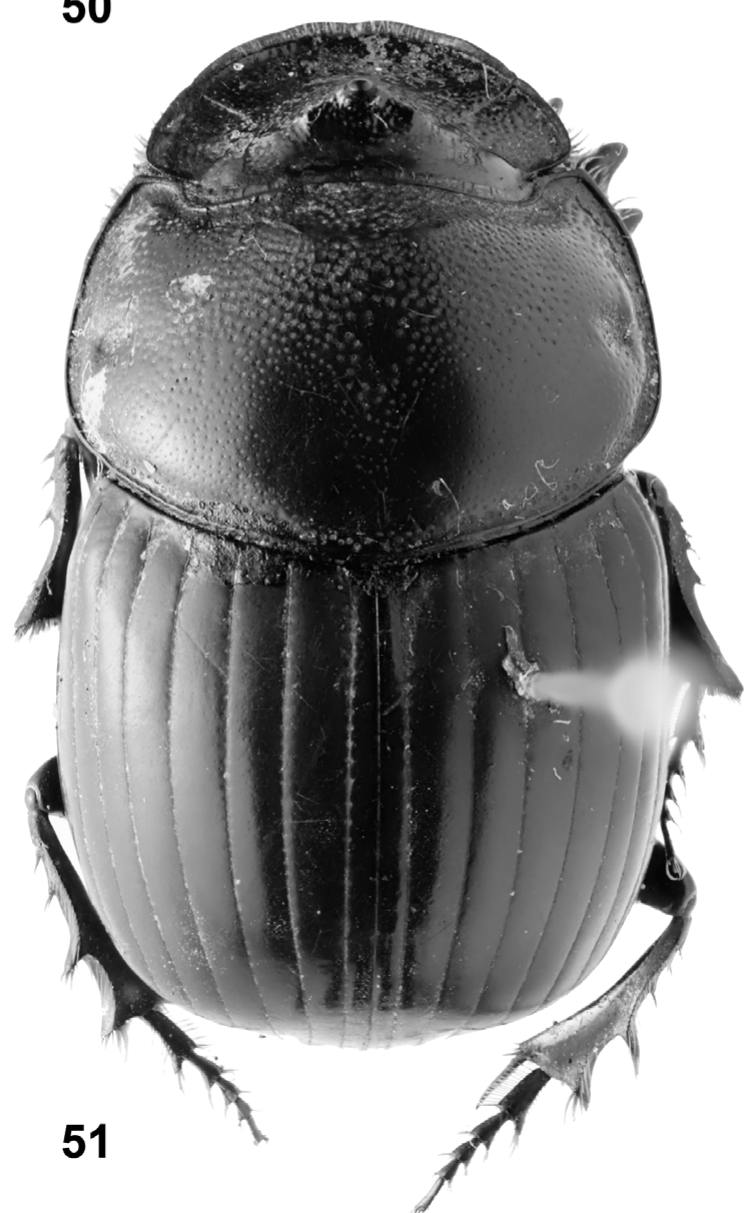

Figs 48-51. Dorsal habitus and form of clypeal apex and pronotal structures. 48 - Copris (Copris) carinicus female, showing clypeal apex with distinct emargination and pronotum with median sulcus; 49-51-C. (C.) iris, male dorsal habitus, clypeal apex, and female dorsal habitus showing clypeal apex without emargination and male pronotum with a large excavation. 


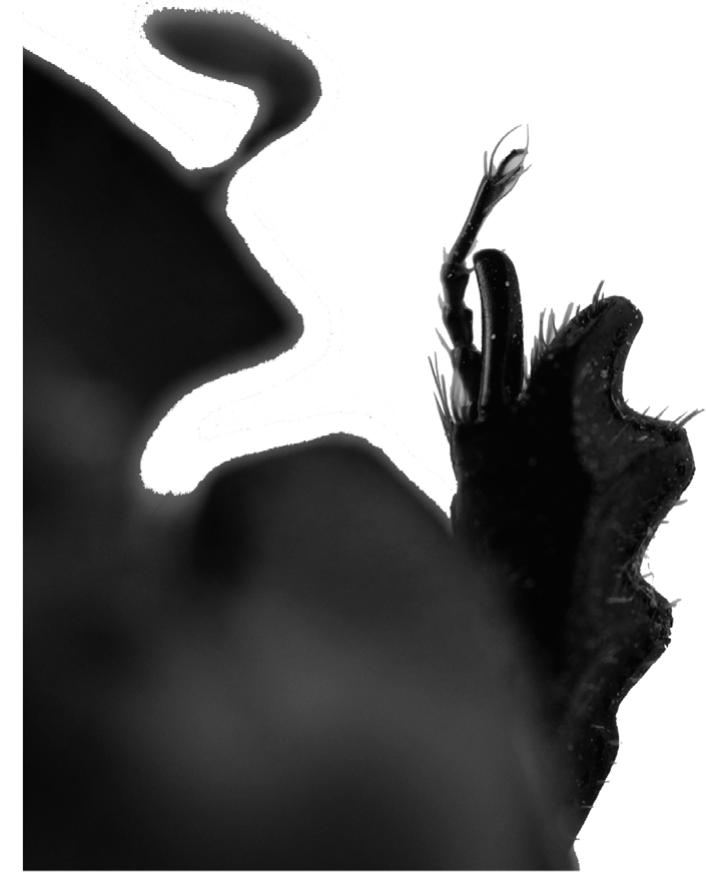

52

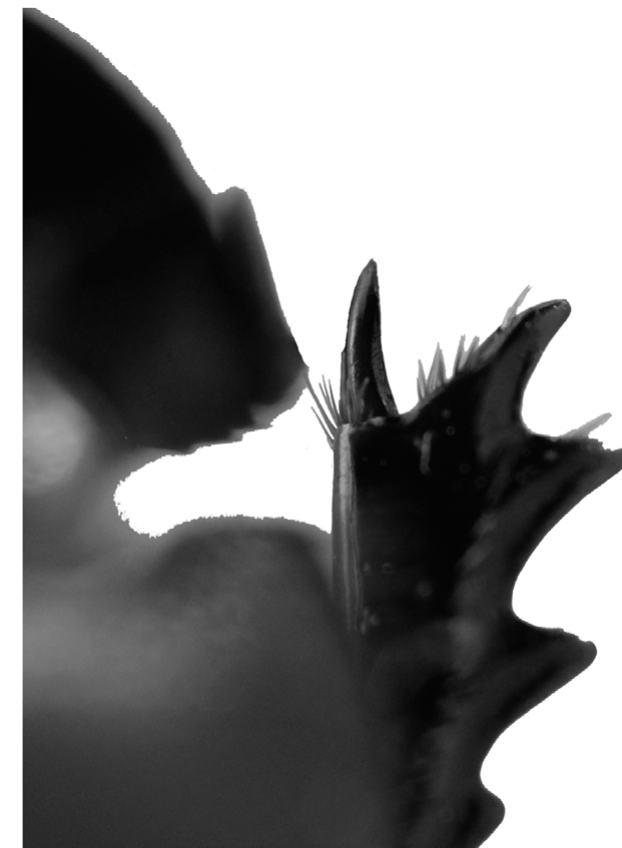

53

Figs 52, 53. Form of protibial spurs. 52 - Copris (Copris) sinicus showing protibial spur curved inwards near apex; 53 - C. (C.) magicus showing protibial spur curved outwards near apex.

10. Copris (Copris) sinicus Hope, 1842. Distribution in Vietnam: North Vietnam (Hagiang, Tuyenquang, Vinhphuc, Quangninh, Sonla, Dienbien provinces), Central Vietnam (Thanhhoa, Nghean, Quangbinh provinces) and South Vietnam (Gialai, Kontum, Dongnai provinces). Habitats recorded: semiarid semi-deciduous tropical forest, secondary tropical forest and cultural landscape; 10 $1800 \mathrm{~m}$ a.s.1. (Kabakov \& Napolov, 1999).

Elsewhere: India, Malaysia, Myanmar, Cambodia and China (Balthasar, 1963; Davis et al., 2001; Hanboonsong et al., 2003; Kabakov \& Shokhin, 2014).

11. Copris (Copris) sonensis sp. n. Collecting details: Thanhhoa Province, 850-960 m a.s.1., secondary forest (9 individuals) and primary forest (3 individuals).

12. Copris (Copris) sorex Balthasar, 1942. Distribution in Vietnam: Tamdao National Park (Vinhphuc Province, northern Vietnam). Habitat recorded: montane tropical forest; 900-1000 m a.s.l. (Kabakov \& Napolov, 1999).

Elsewhere: China (Balthasar, 1963).

13. Copris (Copris) szechouanicus Baltharsar, 1958, a newly recorded species for Vietnam. Distribution in Vietnam: Thanhhoa and Caobang provinces. This species was mainly found in forest with 102 and 125 individuals collected in primary and secondary forest, respectively, while only 27 individuals were collected in meadows; 780-1200 $\mathrm{m}$ a.s.1.

Elsewhere: China (Balthasar, 1963).

14. Copris (Copris) vietnamicus Kabakov, 1994. Known only from Vietnam: Tamdao National Park (Vinhphuc Province, northern Vietnam). Habitat recorded: montane tropical forest; 900-1000 m a.s.1. (Kabakov \& Napolov, 1999).

\section{Subgenus Paracopris Balthasar, 1939}

15. Copris (Paracopris) cariniceps Felsche, 1910. Distribution in Vietnam: North Vietnam (Hagiang, Tuyenquang, Backan provinces) and Central Vietnam (Thanhhoa, Nghean provinces). Habitat recorded: lowland evergreen forest (Kabakov \& Napolov, 1999; Heyes et al., 2009).

Elsewhere: China, Thailand (Balthasar, 1963; Hanboonsong et al., 2003; Kabakov \& Shokhin, 2014).

16. Copris (Paracopris) punctulatus Wiedeman, 1823. Distribution in Vietnam: North Vietnam (Sonla, Dienbien provinces) and Central Vietnam (Quangbinh Province) (Balthasar, 1963; Kabakov \& Napolov, 1999).

Elsewhere: India, Indonesia, Malaysia, Myanmar, Laos, Cambodia, Thailand and China (Balthasar, 1963; Hanboonsong et al., 2003; Sewak, 2009; Shahabuddin, 2010; Bai et al., 2011).

\section{Subgenus Microcopris Balthasar, 1958}

17. Copris (Microcopris) doriae Harold, 1877. Distribution in Vietnam: North Vietnam (Vinhphuc, Laocai provinces) and Central Vietnam (Nghean Province). Habitats recorded: montane tropical forest and secondary savannah, 500-1700 m a.s.1. (Kabakov \& Napolov, 1999).

Elsewhere: Malaysia, Indonesia, "Indochina" and Myanmar (Arrow, 1931; Balthasar, 1963; Davis et al., 2001; Qie et al., 2011; Doll et al., 2014).

18. Copris (Microcopris) miyakei Ochi \& Kon, 2004. Known only from Vietnam: Caobang Province (North Vietnam) (Ochi \& Kon, 2004).

19. Copris (Microcopris) propinquus Felsche, 1910. Distribution in Vietnam: in our surveys, almost all specimens were collected in Thanhhoa Province (115 speci- 

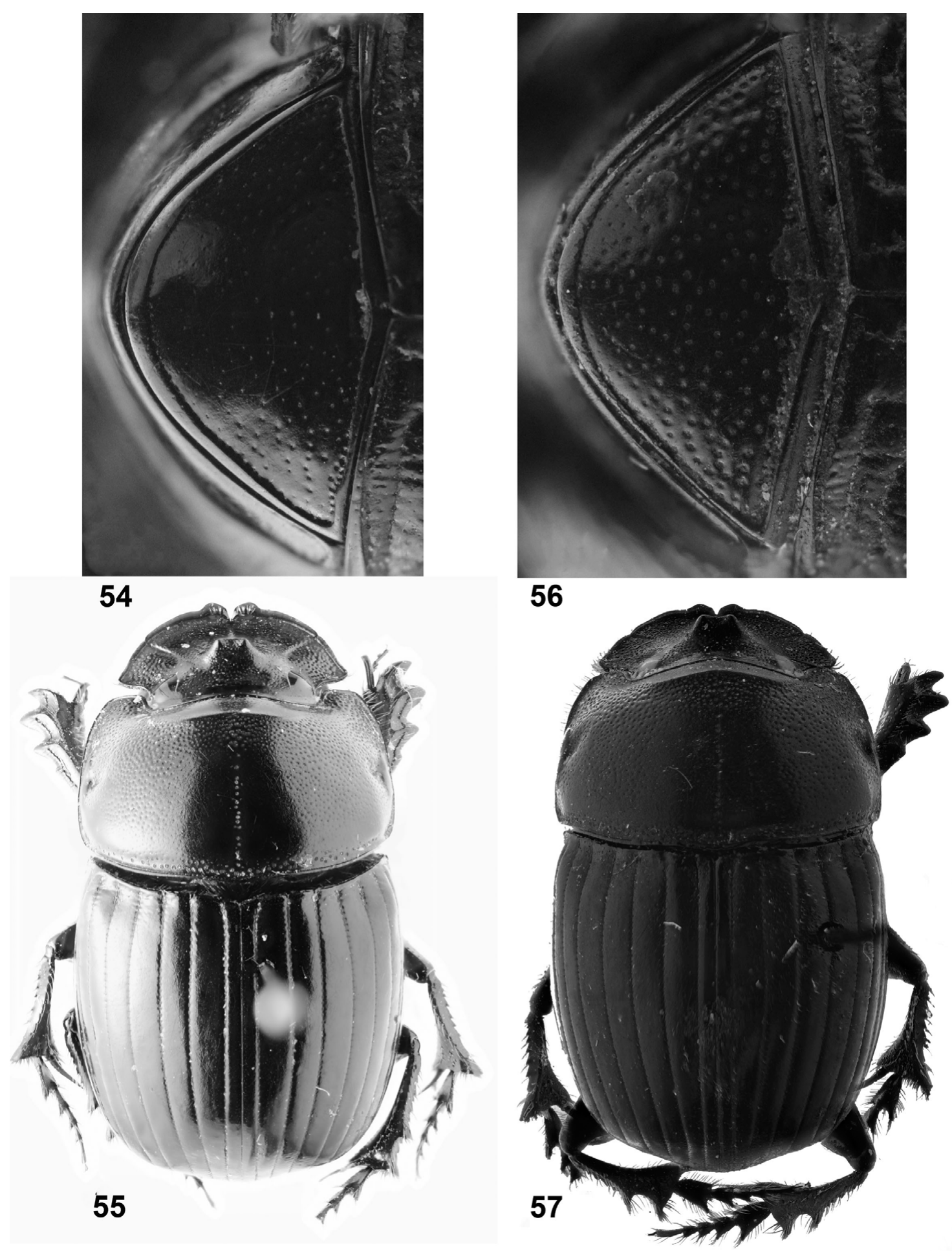

Figs 54-57. Dorsal habitus and pygidium. 54, 55 - Copris (Copris) sinicus, female, pygidium and habitus; 56,57 - C. (C.) carinicus, female, pygidium and habitus.

mens) and only 7 specimens in Caobang Province. Strong preference of $C$. (M.) propinquus for secondary forest with 65 specimens collected in this habitat compared to 44 and 6 specimens in meadows and primary forest, respectively. No specimen was collected in meadows and primary forest in Caobang. According to Kabakov \& Napolov (1999), this species is widespread in North Vietnam (Tuyenquang, Thainguyen, Backan, Vinhphuc, Quangninh provinces), Central Vietnam (Thanhhoa, Nghean, Hatinh, Quangbinh provinces) and South Vietnam (Gialai, Kontum provinces). Habitats recorded: semiarid semi-deciduous tropical forest, montane tropical forest, secondary tropical forest, cultural landscape and secondary savannah; 10-1100 m a.s.l. (Kabakov \& Napolov, 1999; Heyes et al., 2009).

Elsewhere: China, Laos (Balthasar, 1963; Kabakov \& Shokhin, 2014).

20. Copris (Microcopris) reflexus Fabricius, 1787. Distribution in Vietnam: North Vietnam (Hanoi, Hagiang, 

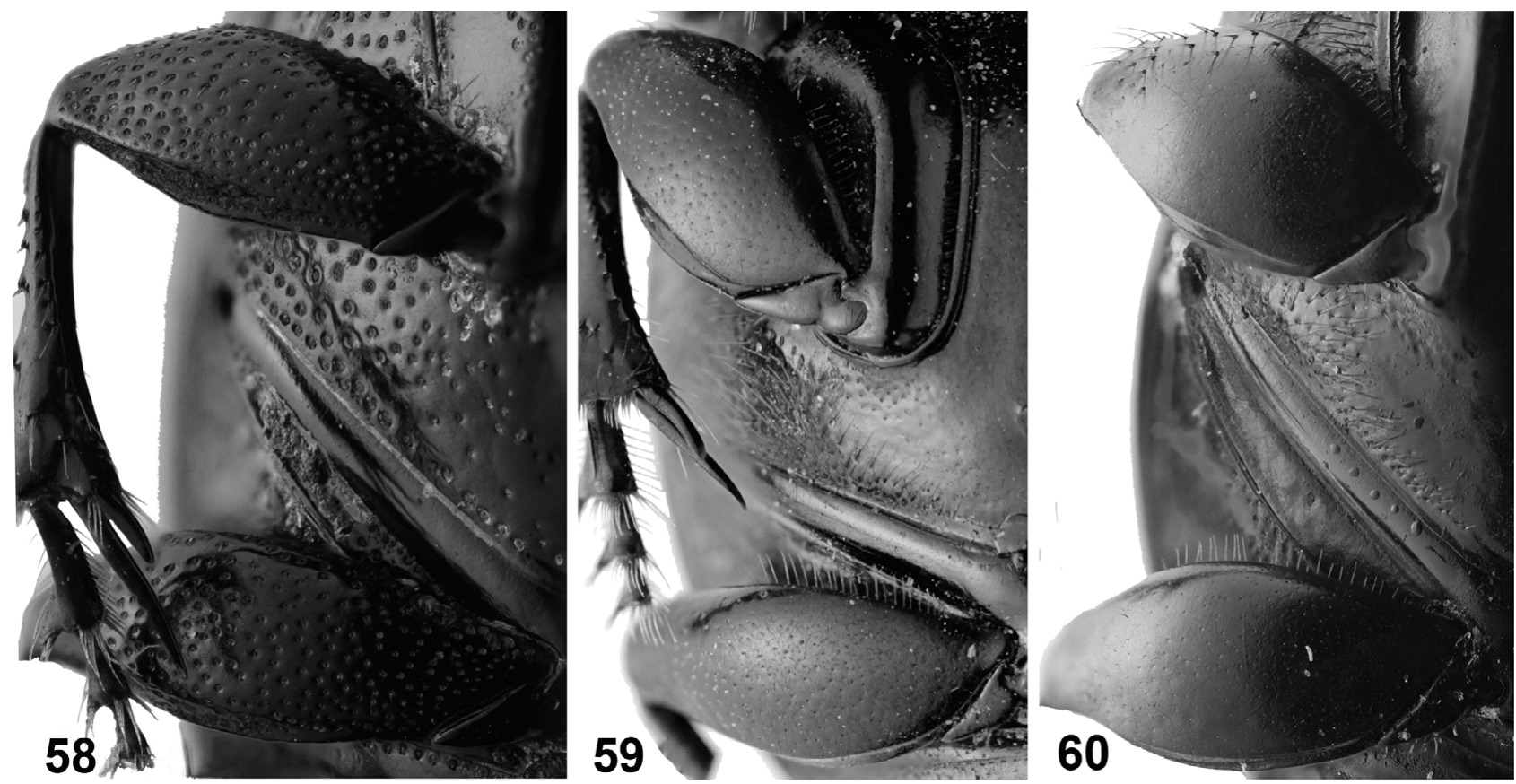

Figs 58-60. Ventral surfaces of right meso- and metafemora. 58 - Copris (Copris) angusticornis, showing deep and coarse punctures; $59-C$. (C.) repertus, showing shallow but distinct punctures, $60-$ C. (C.) magicus, showing indistinct punctures.

Caobang, Backan, Tuyenquang, Thainguyen, Vinhphuc, Langson, Quangninh, Haiphong, Laocai, Hoabinh, Sonla, Laichau, Dienbien provinces), Central Vietnam (Thanhhoa, Nghean, Hatinh, Quangbinh, Quangtri provinces) and South Vietnam (Gialai, Kontum provinces). Habitats recorded: various habitats from forest, meadows to cultural landscape; 10-2000 m a.s.1. (Kabakov \& Napolov, 1999; Heyes et al., 2009).

Elsewhere: "Indochina", Thailand, Myanmar, Malaysia, Indonesia, China and Taiwan (Balthasar, 1963; Davis et al., 2001; Boonrotpong et al., 2004; Kabakov \& Shokhin, 2014).

21. Copris (subgenus incertae sedis) caobangensis $\mathrm{sp} . \mathrm{n}$. Collecting details: Caobang Province, primary forest (3 individuals).

\section{Key to species of Copris recorded from Vietnam}

The key to 21 Vietnamese Copris is based on the specimens examined by us in NMPC, RMNH and VNUF, and data published by Arrow (1931), Balthasar (1933, 1958, 1963), Kabakov (1994), Hanboonsong et al. (2003) and Ochi \& Kon (2004).

The key makes separation of sexes possible for 15 species. Females of two species, C. (Microcopris) miyakei and C. (Copris) vietnamicus are unknown. Both sexes are similar externally (and thus not separated in the key) in four species: C. (Microcopris) reflexus, C. (Copris) corpulentus, C. (C.) confucius and C. (C.) numa.

1 Anterior angles of prothorax with deep excavation on ventral side (Fig. 38).

- Anterior angles of prothorax flat, without excavation on ventral side (Fig. 39) .....

2 Pronotum with transverse carina on the upper part of the anterior declivity (males only, females unknown)....
Pronotum without transverse anterior carina........................ 3

3 Body length 12-16 mm. Maximum elytral width greater than maximum elytral length. Males: cephalic horn short, slender, and curved backwards (Figs 40, 41). Females: cephalic horn indistinct ............................................ (Microcopris) doriae

- Body length 7-11 mm. Maximum elytral length greater than maximum elytral width (Fig. 42) ........................................... 4

4 Clypeal apex with narrow and deep emargination. Both sexes alike externally, with cephalic horn indistinct (Fig. 43) ..........

C. (Microcopris) reflexus

- Clypeal apex with wide and shallow emargination. Males: cephalic horn short but distinct (Fig. 44). Females: cephalic horn indistinct. C. (Microcopris) propinquus

5 Elytral interstriae deeply punctate (Figs 13, 15).................. 6 Elytral interstriae shallowly or indistinctly punctate (Figs 17, 19).

6 Pronotum with sharp anterior declivity. Males: pronotal disc armed with two forwardly directed prominences on dorsal side and one upwardly directed prominence on each side, and with deep excavation on each side. Females: pronotal disc unarmed and without excavations

Pronotum without sharp anterior declivity. Both sexes: pronotal disc unarmed and without excavations ......................... 8

7 Body length 11.8-12.0 mm. Punctures on interstriae and pronotum equal in size. Males: cephalic horn long, curved backwards; clypeal apex with weak emargination (Figs 1, 4). Females: cephalic horn short, straight, excavated at apex; clypeal apex with strong emargination (Figs 7, 10) .....

..C. (subg. incertae sedis) caobangensis sp. $\mathrm{n}$. Body length $14.5 \mathrm{~mm}$. Punctures on interstriae smaller than those on pronotum. Males: cephalic horn nearly straight; clypeal apex with deep emargination. Females unknown ....... C. (Copris) vietnamicus

8 Pronotum and elytra sparsely punctate. Males: clypeal apex protrudes upwards (Fig. 45). Females: clypeal apex truncate. C. (Paracopris) punctulatus Pronotum and elytra densely punctate. Males: clypeal apex indistinctly emarginated and not protruding upwards; ce- 


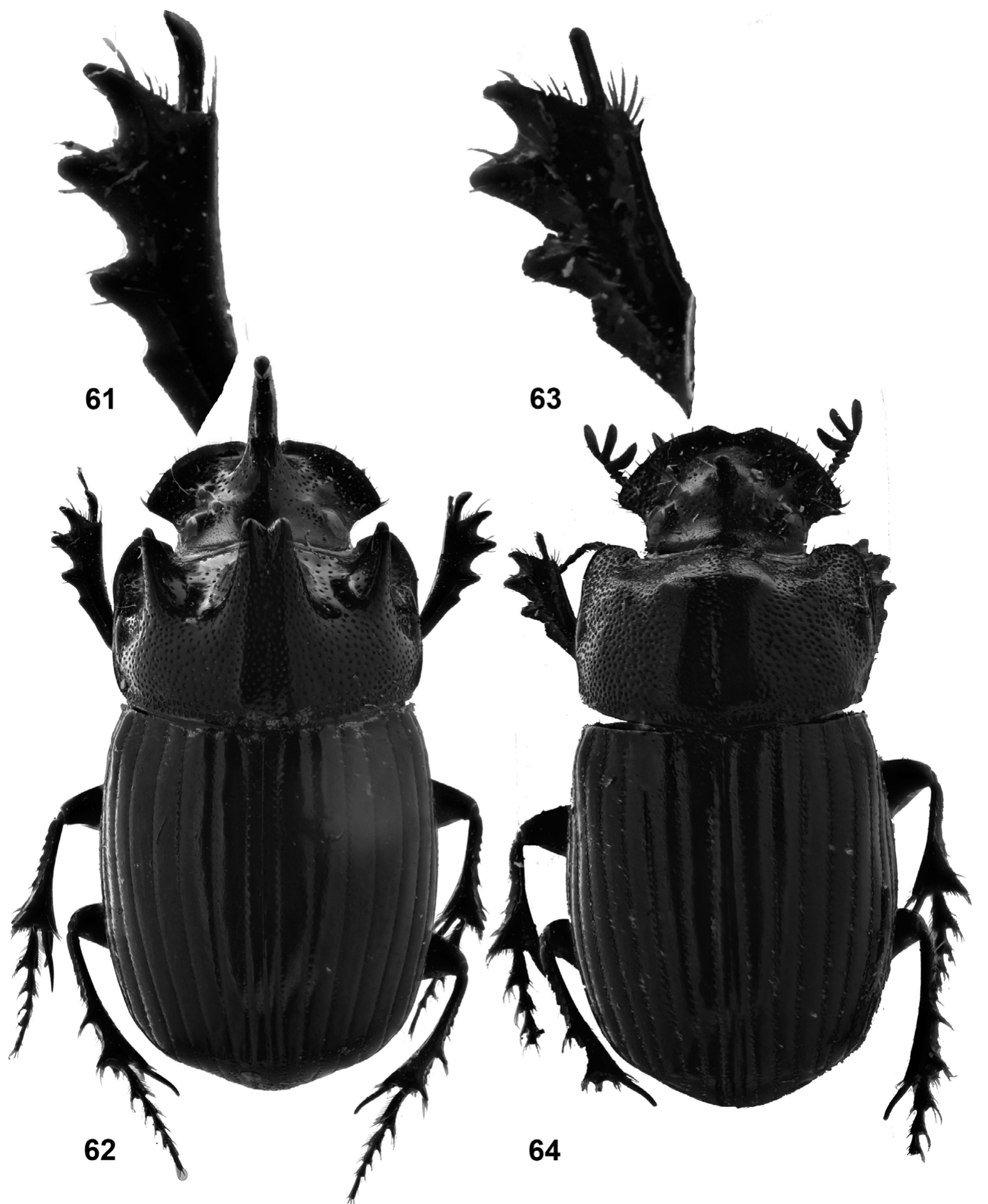

Figs 61-64. Male protibial spurs and dorsal habitus. 61, 62 - Copris (Copris) angusticornis; 63, 64 - C. (C.) sorex.

phalic horn short but distinct. Females: clypeal apex deeply emarginated; cephalic horn indistinct

C. (Paracopris) cariniceps

9 Clypeus and anterior part of genae rugose or deeply punctate (Fig. 46)

- Clypeus and anterior part of genae smooth, almost impunctate (Fig. 47)

10. Clypeal apex with distinct emargination. Pronotum with median sulcus (Fig. 48)

...11

- Clypeal apex without emargination. Pronotum without median sulcus. Males: cephalic horn long, strongly curved backwards; pronotal disc with large excavation (Figs 49, 50). Females: cephalic horn short, straight; pronotal disc without excavation (Fig. 51) ........................................ (Copris) iris

11. Protibial spur curved inwards near apex (Fig. 52)............... 12

- Protibial spur straight or curved outwards near apex (Fig. 53)

12 Pygidium sparsely, weakly and unevenly punctate. Males: pronotal disc with weak prominences; cephalic horn long, slender and with two minute teeth at base. Females: pronotal disc without prominences; cephalic horn short, straight and deeply excavated at apex (Figs 54, 55)..... C. (Copris) sinicus 


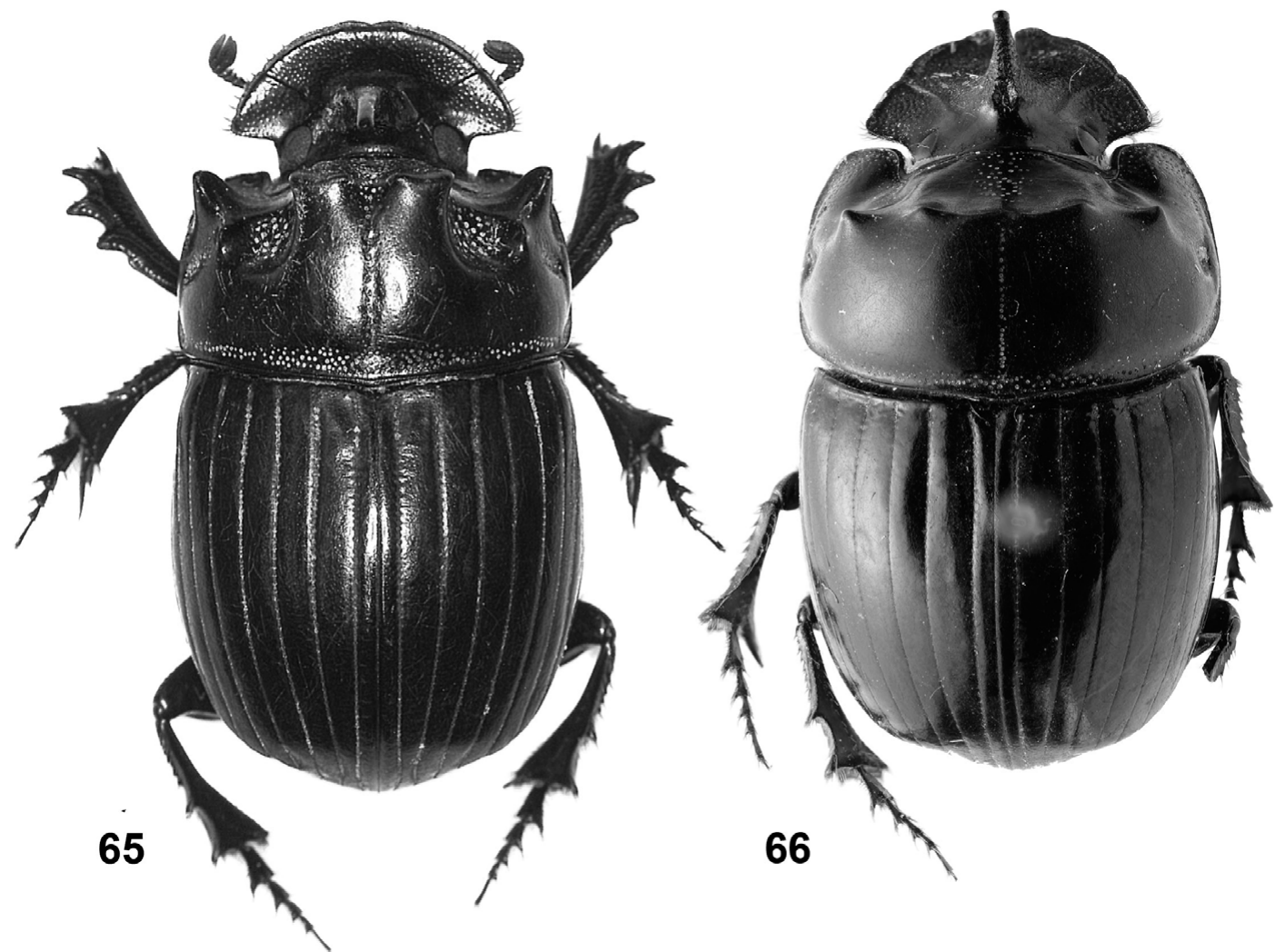

Figs 65,66 . Dorsal habitus. 65 - Copris (Copris) magicus, large male; 66 - C. (C.) repertus, large male.

- Pygidium densely, deeply and evenly punctate. Males: pronotal disc with weak prominences; cephalic horn relatively long, slender and without teeth at base. Females: pronotal disc without prominences; cephalic horn short, straight and slightly excavated at apex (Figs 56, 57)

C. (Copris) carinicus

13 Mesofemora and metafemora strongly and coarsely punctate (Fig. 58)

- Mesofemora and metafemora weakly (Fig. 59) or indistinctly punctate (Fig. 60).

14 Body length $11.5-14.0 \mathrm{~mm}$. Protibial spur curved outwards near apex. Males: cephalic horn long (4.5-5.5 mm); pronotal disc with strong prominences on dorsal side and with deep excavations on each side (Figs 61, 62). Females: cephalic horn short (1.5-2 $\mathrm{mm})$; pronotal disc without prominences and not excavated on each side...... C. (Copris) angusticornis - Body length 9.5-11.0 mm. Protibial spur straight. Males: cephalic horn short (approximately $1.5 \mathrm{~mm}$ ); pronotal disc without prominences on dorsal side, and with a weak excavation on each side (Figs 63, 64). Females: cephalic horn indistinct; frons slightly swollen; pronotal disc without prominences, and not excavated C. (Copris) sorex
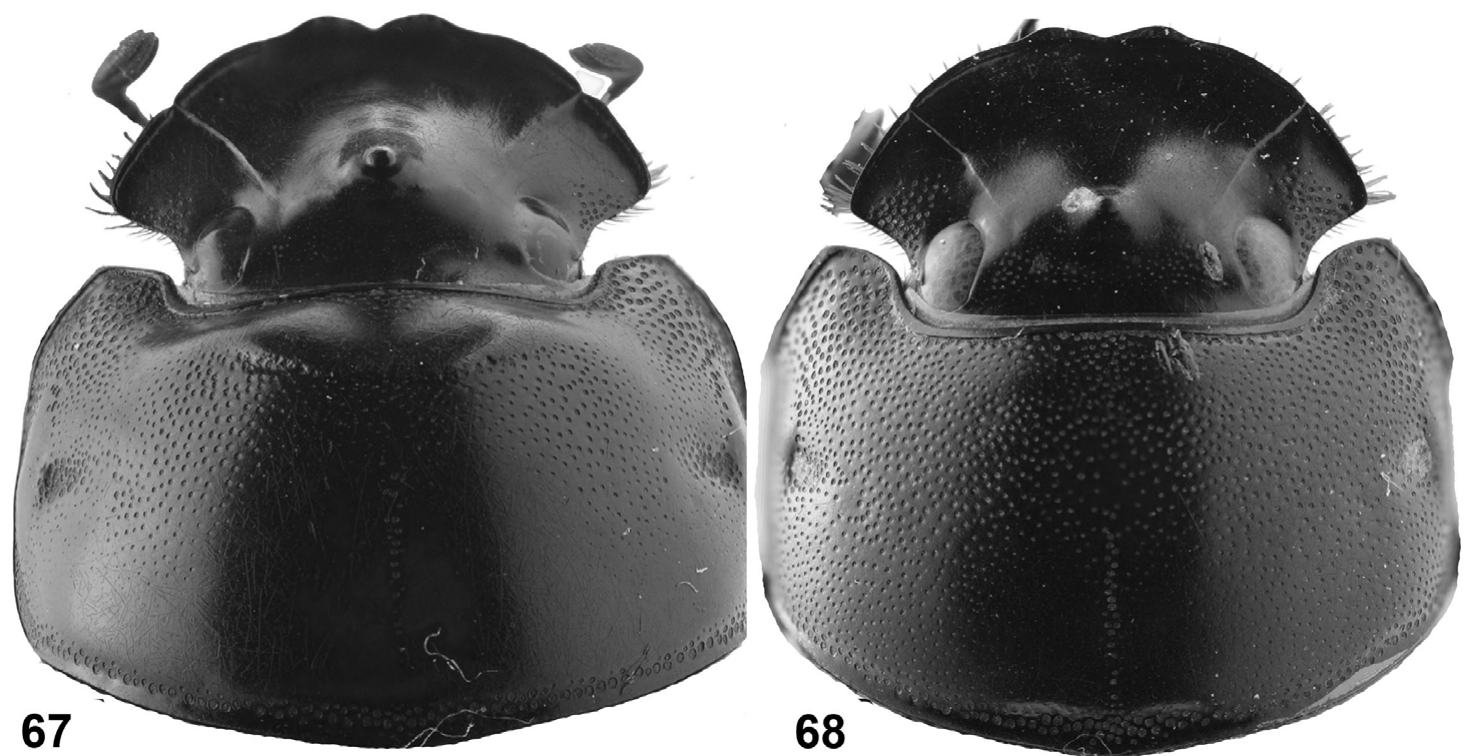

Figs 67 , 68. Form of pronotum. 67 - Copris (Copris) szechouanicus showing pronotum with sharp anterior declivity; $68-C$. (C.) numa showing pronotum without sharp anterior declivity. 


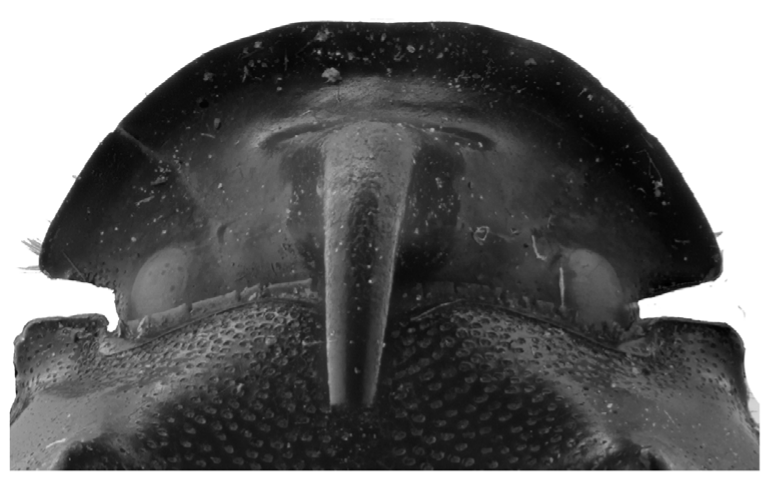

69



71 


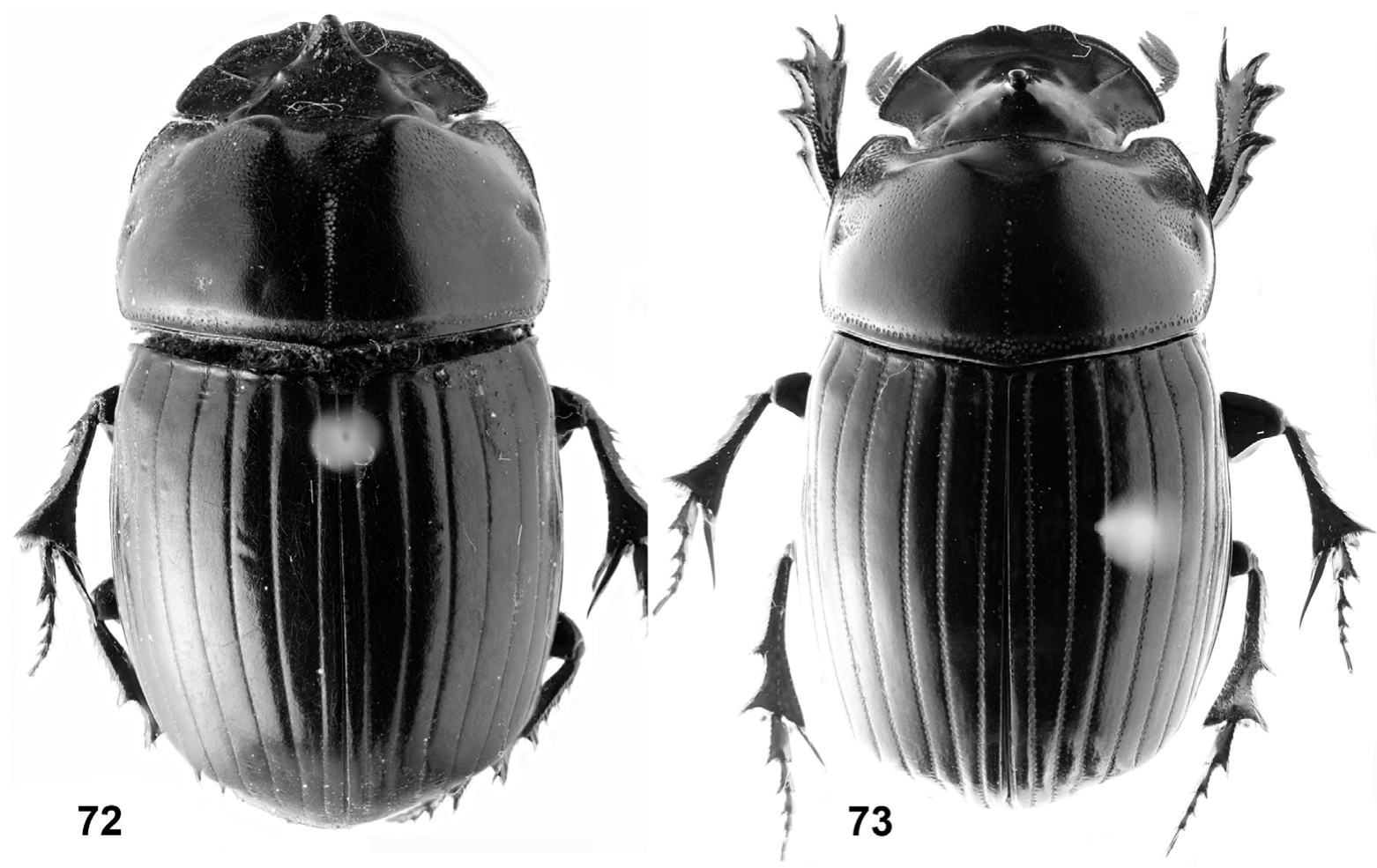

Figs 72, 73. Dorsal habitus. 72 - Copris (Copris) corpulentus; 73 - C. (C.) szechouanicus, female.

two small teeth at base; large individuals: pronotal disc with weak excavation on each side (Fig. 66); small individuals without excavations; Females: cephalic horn short, straight and excavated at apex. C. (Copris) repertus

16 Pronotum with sharp anterior declivity (Fig. 67) ................ 17

- Pronotum without sharp anterior declivity (Fig. 68) ........... 20

17 Clypeal apex without emargination. Males: cephalic horn long and strongly curved backwards; pronotal disc with one large central excavation (Figs 69, 70). Females: cephalic horn short and straight; pronotal disc without excavation .

.. . (Copris) nevinsoni

- Clypeal apex with distinct emargination (Fig. 71) .............. 18

18 Medium sized species, body length $13.3-15.2 \mathrm{~mm}(\mathrm{n}=9)$. Males: pronotum with a deep excavation along each side; cephalic horn long, slightly curved backwards (Figs 20, 32). Females: pronotum without excavations; cephalic horn short, straight and strongly excavated at apex (Figs 27, 29) .C. (Copris) sonensis sp. n.

- Large species, body length 15-21 mm. Both sexes: pronotum without excavations on each side; cephalic horn short, straight and pointed (not excavated)...

19 Anterior part of pronotum with pair of protuberances. Both sexes alike externally (Fig. 72)......... C. (Copris) corpulentus Pronotum with transverse carina on upper part of anterior declivity. Males: pronotal carina interrupted by longitudinal sulcus. Females: pronotal carina not interrupted (Fig. 73) .....

C. (Copris) szechouanicus

20 Vertex with deep and contiguous punctures. Punctures on genae deep, dense and surround eyes. Clypeal apex with narrow and deep emargination. Both sexes alike externally (Figs $74,75)$ C. (Copris) confucius

- Vertex with punctures separate. Punctures on genae shallow and do not surround eyes. Clypeal apex with wide and shallow emargination. Both sexes alike externally (Figs 75, 76) .

C. (Copris) numa

\section{Molecular analysis}

Analysis of the cytochrome oxidase I sequences (Table 1; Onthophagus was used as outgroup) resolved monophyletic and well supported genera Copris and Catharsius (Appendix 1). Both Maximum Likelihood analysis and MrBayes provided trees with the same conformation. Copris sonensis sp. n. was clearly distant from other available Copris species and the male and female showed only slight differences (three base pairs) in their COXI gene sequences.

ACKNOWLEDGEMENTS. We are grateful to T. Ochi (Osaka, Japan), M. Kon (Shiga, Japan) and M. Bai (Institute of Zoology, Chinese Academy of Sciences, Beijing) for providing literature for the identification of Southeast Asian dung beetles. We would like to express particular thanks to J. Hájek (National Museum, Prague, Czech Republic) and H. Huijbregts (Naturalis Biodiversity Center, Leiden, the Netherlands for permission to examine the specimens deposited in their museums. Comments from the editor and two anonymous reviewers greatly improved this manuscript. This research received support from the SYNTHESYS Project (http://www.synthesys.info/) financed by the European Community Research Infrastructure Action under the FP7 Integrating Activities Programme. Ministry of Education and Training of Vietnam (MOET, Project 911), and Idea Wild, 420 Riddle Drive, Fort Collins, CO 80521, USA funded Van Bac Bui's field surveys in Vietnam.

\section{REFERENCES}

Altekar G., Dwarkadas S., Huelsenbeck J.P. \& Ronquist F. 2004: Parallel metropolis coupled Markov chain Monte Carlo for Bayesian phylogenetic inference. - Bioinformatics 20: 407-415. 

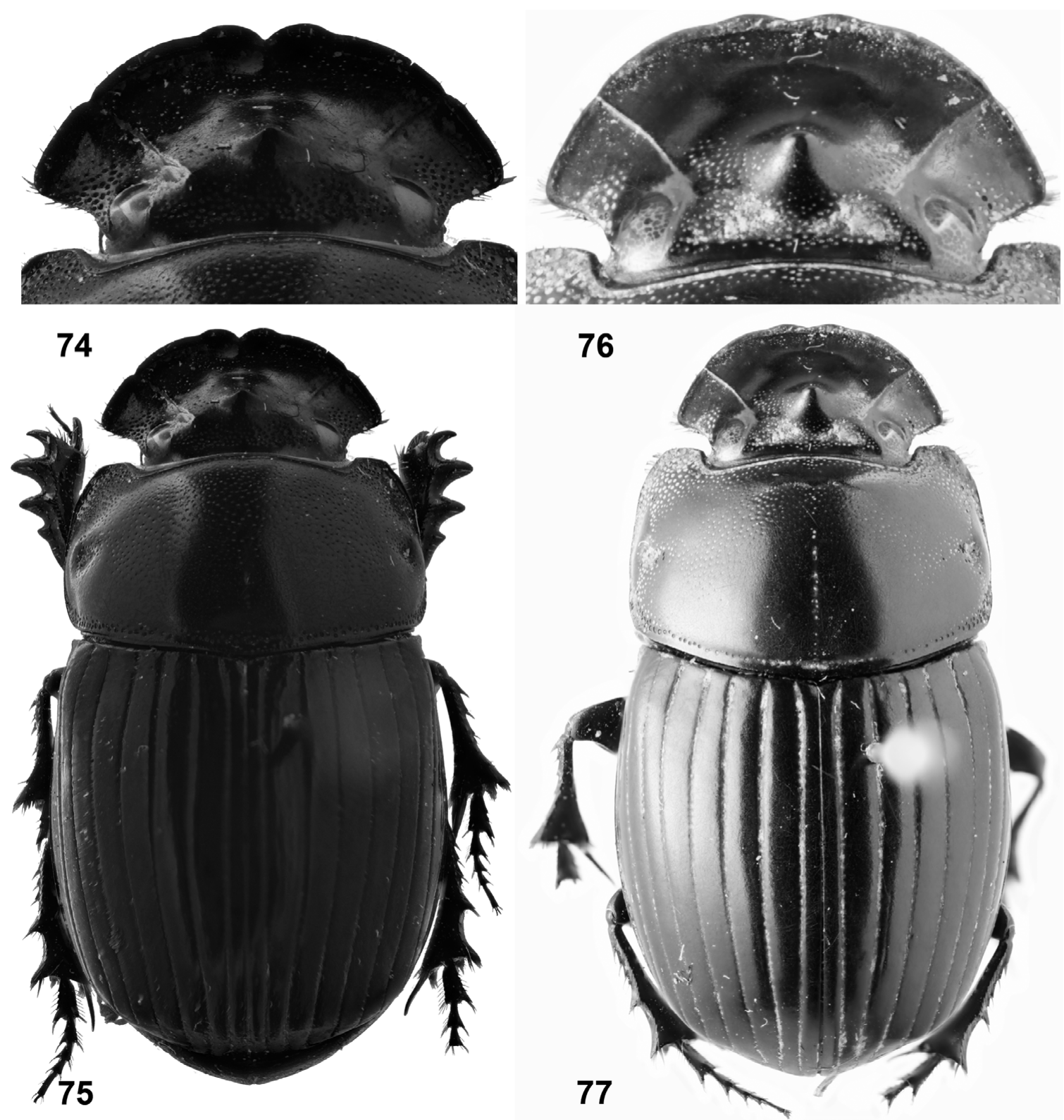

Figs 74-77. Dorsal habitus and form of clypeus. 74, 75- Copris (Copris) confucius showing clypeal apex with narrow and deep emargination; $76,77-C$. (C.) numa showing clypeal apex with wide and shallow emargination.

ARrow G.J. 1931: The fauna of British India, including Ceylon and Burma. Coleoptera Lamellicornia. Part III (Coprinae). Taylor and Francis, London, 428 pp.

Bai M., McCullough E., Song K.-Q., Liu W.-G. \& Yang X.-K. 2011: Evolutionary constraints in hind wing shape in Chinese dung beetles (Coleoptera: Scarabaeinae). — PLOS ONE 6(6): e21600, $12 \mathrm{pp}$.

Balthasar V. 1933: Die chinesischen Copris-Arten mit Beschreibung von zwei neuen Arten (Col.). - Stett. Entomol. Ztg 94: 263-273.

Balthasar V. 1958: Eine neue Untergattung und einige neue Arten der Gattung Copris Geoffroy. - Acta Entomol. Mus. Natn. Pragae 32: 471-480.

Balthasar V. 1963: Monographie der Scarabaeidae und Aphodiidae der Palaearktischen und Orientalischen Region. Coleoptera: Lamellicornia. Band 1. Allgemeiner Teil, Systematischer Teil: 1. Scarabaeinae, 2. Coprinae (Pinotini, Coprini). Verlag der Tschechoslowakischen Akademie der Wissenschaften, Prag, 391 pp.
Boonrotpong S., Sotthibandhu S. \& Pholpunthin C. 2004: Species composition of dung beetles in the primary and secondary forests at Ton Nga Chang Wildlife Sanctuary. - ScienceAsia 30: $59-65$.

Davis A.J., Holloway J.D., Huijbregts H., Krikken J., KirkSpriggs A.H. \& Sutton S.L. 2001: Dung beetles as indicators of change in the forests of northern Borneo. - J. Appl. Ecol. 38: $593-616$.

Davis A.L.V., Frolov A.V. \& Scholtz C.H. 2008: The African Dung Beetle Genera. Protea Book House, Pretoria, 272 pp.

Doll H.M., Butod E., Harrison R.D., Fletcher C., Kassim A.R., IBRAHIM S. \& PotTs M.D. 2014: Environmental and geographic factors driving dung beetle (Coleoptera: Scarabaeidae: Scarabaeinae) diversity in the dipterocarp forests of Peninsular Malaysia. - Raffles Bull. Zool. 62: 549-560.

Gillet J.J.E. 1911: Coprides nouveaux de la région orientale et remarques synonymiques. - Ann. Soc. Entomol. Belg. 55: 313-314. 
Gouy M., Guindon S. \& Gascuel O. 2010: SeaView version 4: a multiplatform graphical user interface for sequence alignment and phylogenetic tree building. - Mol. Biol. Evol. 27: 221-224.

Guindon S. \& Gascuel O. 2003: A simple, fast, and accurate algorithm to estimate large phylogenies by maximum likelihood. - Syst. Biol. 52: 696-704.

Hanboonsong Y., Masumoto K. \& Ochi T. 2003: Dung beetles (Coleoptera, Scarabaeidae) of Thailand. Part 5. Genera Copris and Microcopris (Coprini). - Elytra 31: 103-124.

Hanski I. \& Cambefort Y. 1991: Dung Beetle Ecology. Princeton University Press, Princeton, 481 pp.

Heyes L., Mann D.J., Monastyrskit A.L. \& Lewis O.T. 2009: Rapid assessments of tropical dung beetle and butterfly assemblages: contrasting trends along a forest disturbance gradient. - Insect Conserv. Divers. 2: 194-203.

KabaKov O.N. 1994: New species of lamellicorn beetles of the subfamily Scarabaeinae (Coleoptera, Scarabaeidae) from Vietnam and adjacent countries. - Entomol. Obozr. 73: 300-317.

Kabakov O.N. \& NAPOLOV A. 1999: Fauna and ecology of Lamellicornia of subfamily Scarabaeinae of Vietnam and some parts of adjacent countries: South China, Laos, and Thailand. - Latv. Entomol. 37: 58-96.

KabaKov O.N. \& SHoKhIN I.V. 2014: Contribution to the knowledge of the subfamily Scarabaeinae (Coleoptera) from China with nomenclatural notes. - Caucas. Entomol. Bull. 10: 4759.

Medina C.A., Molano F. \& Scholtz C.H. 2013: Morphology and terminology of dung beetles (Coleoptera: Scarabaeidae: Scarabaeinae) male genitalia. - Zootaxa 3626: 455-476.

Mlambo S., Sole C.L. \& Scholtz C.H. 2015: A molecular phylogeny of the African Scarabaeinae (Coleoptera: Scarabaeidae). - Arthr. Syst. Phylogen. 73: 303-321.

Monaghan M.T., Inward D.J., Hunt T. \& Vogler A.P. 2007: A molecular phylogenetic analysis of the Scarabaeinae (dung beetles). - Mol. Phylogenet. Evol. 45: 674-692.
Ochi T. \& Kon M. 2004: Notes on the coprophagous scarabbeetles (Coleoptera, Scarabaeidae) from Southeast Asia (IV). A new horned species of Microcopris from Vietnam and a new subspecies of Copris erratus from Peleng off Sulawesi. - Kogane 5: 25-30.

Ochi T., Kon M. \& Kawahara M. 2008: Four new species of the genus Copris (Coleoptera: Scarabaeidae) from Cambodia and Myanmar. - Entomol. Rev. Japan 62: 243-253.

Ochi T., Kon M. \& BaI M. 2009: Three new species of Copris (Coleoptera: Scarabaeidae) from China, with description of a new subgenus. — Entomol. Rev. Japan 64: 207-216.

QIe L., LeE T.M., Sodhi N.S. \& Lim S.L.-H. 2011: Dung beetle assemblages on tropical land-bridge islands: small island effect and vulnerable species. — J. Biogeogr. 38: 792-804.

RonQuist F. \& HueLSENBECK J.P. 2003: MrBayes 3: Bayesian phylogenetic inference under mixed models. - Bioinformatics 19: $1572-1574$.

SAbU T.K., Vinod K.V. \& Vineesh P.J. 2006: Guild structure, diversity and succession of dung beetles associated with Indian elephant dung in South Western Ghats forests. - J. Insect Sci. 6:17, $12 \mathrm{pp}$.

SEWAK R. 2009: Dung beetles (Coleoptera: Scarabaeidae: Coprinae) of Rajasthan. - Rec. Zool. Surv. India 296: 1-106.

ShaHABUdDIN 2010: Diversity and community structure of dung beetles (Coleoptera: Scarabaeidae) across a habitat disturbance gradient in Lore Lindu National Park, Central Sulawesi. - Biodiversitas 11: 29-33.

Swofford D.L. 2002: PAUP. Phylogenetic Analysis Using Parsimony (and Other Methods). Ver. 4. Sinauer Associates, Sunderland, MA, $142 \mathrm{pp}$.

Wirta H.K., Orsini L. \& Hanski I.A. 2008: An old adaptive radiation of forest dung beetles in Madagascar. - Mol. Phylogen. Evol. 47: 1076-1089.

Received September 28, 2017; revised and accepted March 3, 2018 Published online April 26, 2018 


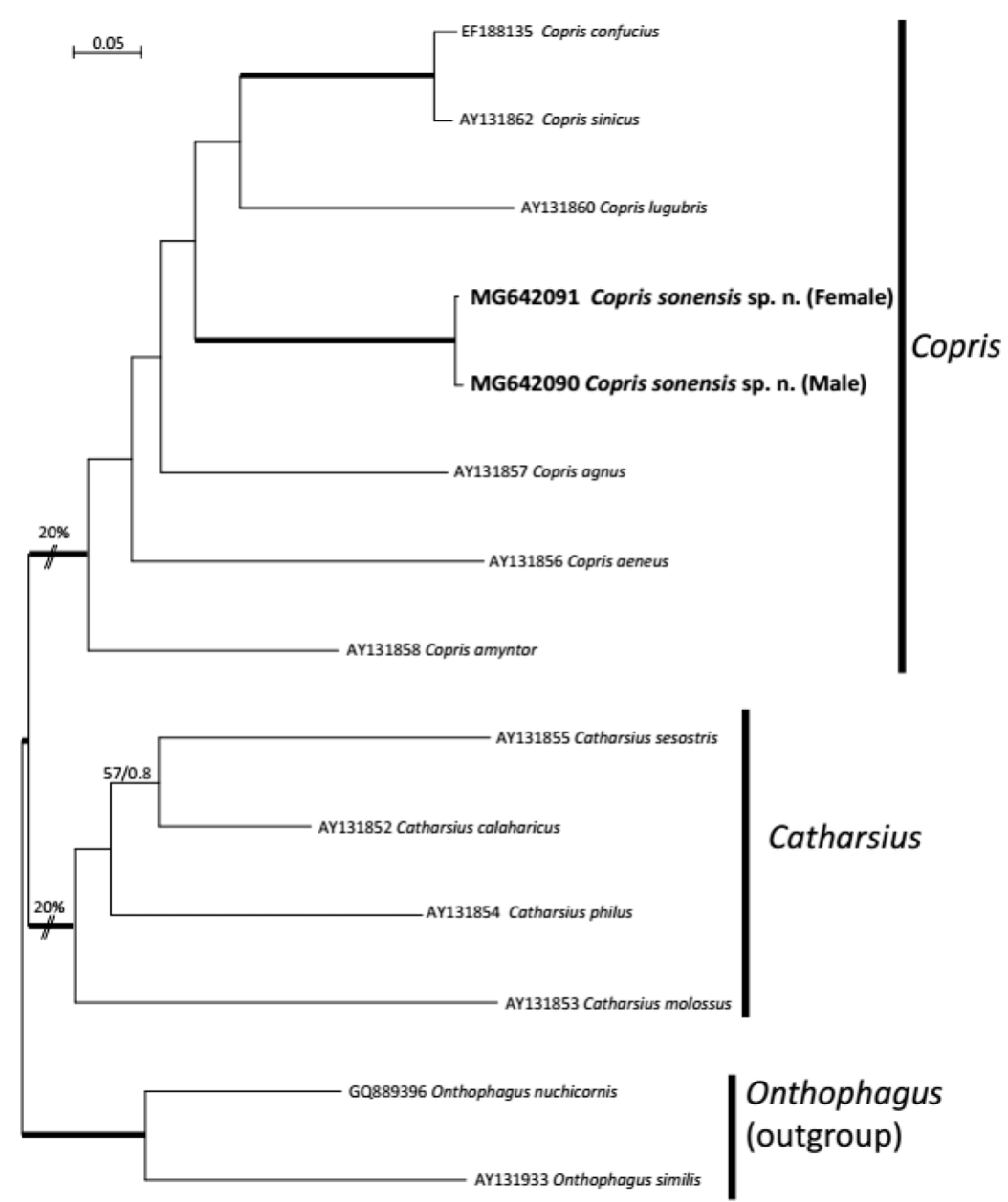

Appendix 1. Molecular relationships of Copris and Catharsius based on COXI; Onthophagus was used as the outgroup. Shown is the maximum likelihood tree obtained using the PhyML GTR+I+G analyses including 14 sequences and 837 aligned sites of which $67.03 \%$ were invariant. The support levels of the PhyML and the Bayesian analysis are shown on the respective branches (ML/BI) if support was over 50 BP/0.8 PP. Bold lines indicate bootstrap support > 99\%. Support under $50 \%$ or 0.8 are omitted. Some branches were reduced to $20 \%$ of their branch length (//) to improve readability of the tree. The beetles sequenced in this study are highlighted in bold. 